\title{
A Review of Biohydrogen Productions from Lignocellulosic Precursor via Dark Fermentation: Perspective on Hydrolysate Composition and Electron-Equivalent Balance
}

\author{
Yiyang Liu ${ }^{1}$, Jingluo Min ${ }^{1}$, Xingyu Feng ${ }^{1}$, Yue $\mathrm{He}^{1}{ }^{1}$, Jinze Liu ${ }^{1}$, Yixiao Wang ${ }^{1}$, Jun $\mathrm{He}^{1}{ }^{1}$, \\ Hainam Do ${ }^{1}$, Valérie Sage ${ }^{2, *(\mathbb{D})}$, Gang Yang ${ }^{3}$ and Yong Sun ${ }^{1,4, *(\mathbb{C})}$ \\ 1 Department of Chemical and Environmental Engineering, University of Nottingham Ningbo China, \\ 199 Taikang E Rd, Ningbo 315100, China; yiyangliu0904@163.com (Y.L.); zy18412@nottingham.edu.cn (J.M.); \\ slyxf3@nottingham.edu.cn (X.F.); slyyh9@nottingham.edu.cn (Y.H.); Jinze.Liu@nottingham.edu.cn (J.L.); \\ shyyw12@nottingham.edu.cn (Y.W.); jun.he@nottingham.edu.cn (J.H.); \\ Hainam.Do@nottingham.edu.cn (H.D.) \\ 2 The Commonwealth Scientific and Industrial Research Organization (CSIRO), Australian Resources \\ Research Centre 26 Dick Perry Avenue, Kensington Energy Business Unit, Perth, WA 6155, Australia \\ 3 State Key Laboratory of Biochemical Engineering, Institute of Process Engineering, \\ Chinese Academy of Sciences, Beijing 100190, China; gangyang@ipe.ac.cn \\ 4 Department of Chemical Engineering, School of Engineering, Edith Cowan University, \\ 270 Joondalup Drive Joondalup, Perth, WA 6027, Australia \\ * Correspondence: valerie.sage@csiro.au (V.S.); y.sun@ecu.edu.au (Y.S.)
}

Received: 11 April 2020; Accepted: 7 May 2020; Published: 13 May 2020

check for updates

\begin{abstract}
This paper reviews the current technological development of bio-hydrogen $\left(\mathrm{BioH}_{2}\right)$ generation, focusing on using lignocellulosic feedstock via dark fermentation (DF). Using the collected reference reports as the training data set, supervised machine learning via the constructed artificial neuron networks (ANNs) imbedded with feed backward propagation and one cross-out validation approach was deployed to establish correlations between the carbon sources (glucose and xylose) together with the inhibitors (acetate and other inhibitors, such as furfural and aromatic compounds), hydrogen yield (HY), and hydrogen evolution rate (HER) from reported works. Through the statistical analysis, the concentrations variations of glucose $(\mathrm{F}-\mathrm{value}=0.0027)$ and acetate (F-value $=0.0028)$ were found to be statistically significant among the investigated parameters to HY and HER. Manipulating the ratio of glucose to acetate at an optimal range (approximate in 14:1) will effectively improve the $\mathrm{BioH}_{2}$ generation (HY and HER) regardless of microbial strains inoculated. Comparative studies were also carried out on the evolutions of electron equivalent balances using lignocellulosic biomass as substrates for $\mathrm{BioH}_{2}$ production across different reported works. The larger electron sinks in the acetate is found to be appreciably related to the higher HY and HER. To maintain a relative higher level of the $\mathrm{BioH}_{2}$ production, the biosynthesis needs to be kept over $30 \%$ in batch cultivation, while the biosynthesis can be kept at a low level (2\%) in the continuous operation among the investigated reports. Among available solutions for the enhancement of $\mathrm{BioH}_{2}$ production, the selection of microbial strains with higher capacity in hydrogen productions is still one of the most phenomenal approaches in enhancing $\mathrm{BioH}_{2}$ production. Other process intensifications using continuous operation compounded with synergistic chemical additions could deliver additional enhancement for $\mathrm{BioH}_{2}$ productions during dark fermentation.
\end{abstract}

Keywords: biohydrogen; lignocellulosic precursor; artificial neuron networks; electron-equivalent balance; process intensification; review 


\section{Introduction}

Although the idea of hydrogen economy was firstly proposed in the early 1970s, it was not until the dawn of the 21st century that industry and academia realize its pivotal potential in shaping a future sustainable society [1-4]. The status quo of existing gaps in the hydrogen economy lies in the cost-effective and reliable hydrogen generation, storage, and utilization, which are the main blocks in the chain of hydrogen economy [5-7]. Among them, the cost-effective and reliable hydrogen generation is one of the most challenging and difficult barriers to be overcome [8-11]. At present, hydrogen is predominantly produced via a thermal route on the industrial scale. The thermal-catalytic conversion processes are: steam reforming (SR), partial oxidation (POX), and auto-thermal reforming (ATR) [12]. Although the steam reforming of methane (SRM) is currently the most cost-effective approach in industrial scale hydrogen generation, its significant drawbacks of large green-house gas emission and heavy reliance on fossil derived material will significantly deteriorate its future prospects [13]. Apart from using fossil-based material as feedstock, the biomass, which is the world's fourth largest energy resource and contains about $5-7 \mathrm{wt}$. \% of hydrogen element on the dry basis, is emerging as a significant contributor in hydrogen generation [14-16]. In addition to deploying thermal techniques to convert biomass into energy, the biochemical approach via anaerobic and aerobic processes gradually steps in and becomes attractive in both academia and industry [17-19]. The produced hydrogen, so-called biohydrogen $\left(\mathrm{BioH}_{2}\right)$, has begun to provide supplementary subsidize for the entire hydrogen productions due to its inherent advantages such as insensitivity to the moisture of raw materials, mild operational conditions (low temperature and atmospheric pressure), less theoretical energy intensity, and suitability in decentralized energy productions [20-22]. $\mathrm{BioH}_{2}$ production can be achieved via two-type of biological metabolisms, namely photo-dependent (photo-fermentation-PF and bio-photolysis-BP) and photo-independent (dark fermentation-DF) processes [23]. In addition, these processes are apt to be coupled either sequentially or simultaneously on the basis of energy and material cascade utilization and process intensification [24]. The growing trend of publications collected from Scopus (Figure 1) witnessed the endeavors that worldwide scholars have made for the $\mathrm{R} \& \mathrm{D}$ of $\mathrm{BioH}_{2}$ production using biomass as substrate. 


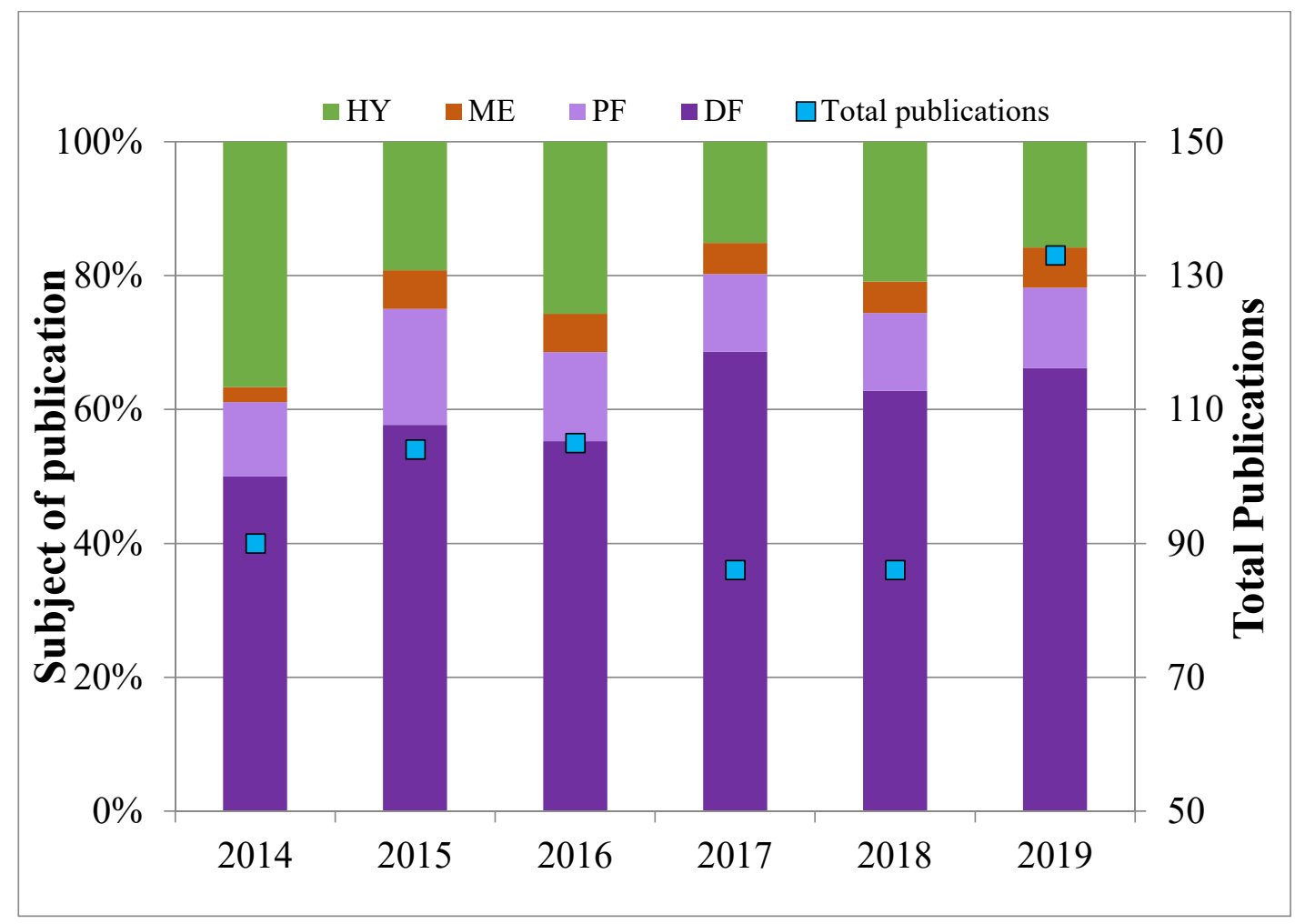

Figure 1. Summary of publications from Scopus in regard to $\mathrm{BioH}_{2}$ production from biomass via dark fermentation (DF), photo fermentation (PF), microbial electrolysis (ME), and hybrid (HY, combined process including $\mathrm{DF}, \mathrm{PF}$, or $\mathrm{ME}$ ).

The discernible dominant fraction of publications (Figure 1) comes from $\mathrm{BioH}_{2}$ productions via DF due to its inherent appealing features such as independence to light, easiness in operation, higher hydrogen conversion, flexibility in cultivation, and simultaneous utilization of organic substrate $[25,26]$. The reports on the combination of DF, PF, or ME maintain at the numbers of 30-50 and the core challenges in combining the photo-dependent, photo-independent, and microbial electrolysis techniques into an integrated $\mathrm{BioH}_{2}$ process still awaiting being tackled $[27,28]$. In regard to the utilization of biomass, although the lignocellulosic biomass is notorious for its recalcitrant nature to the pretreatment (i.e., acid hydrolysis, alkaline delignification, and steam explosion) and the liberation of inhibitory chemicals to the subsequent process, inevitably weakening its fermentation performance in $\mathrm{BioH}_{2}$ production, its abundant availability and allusive economic impetus make the $\mathrm{BioH}_{2}$ production from lignocellulosic biomass as one of the most attractive renewable fuel production processes $[29,30]$. Consequently, the emerging consolidated bioprocess (CBP) successfully integrating the pretreatment and the fermentation to desirable metabolic products has gained substantial research attention in the last five years [18,31].

To narrow the scope of discussions and align with the consensus on the advantage of DF, this review will mainly focus on the $\mathrm{BioH}_{2}$ productions via DF using biomass, especially lignocellulose as the feedstock. In this paper, instead of making simple $\mathrm{BioH}_{2}$ production comparisons across literature reports, the collected data (such as HY, HER, and compositions matrix in the hydrolysate) were used to construct the data matrix for supervised machine learning using the developed artificial neuron networks (ANNs) via the feed backward propagation with one cross out validation approach for more insightful and quantitative correlations between the key operational parameters and performance parameters of $\mathrm{BioH}_{2}$ productions. In addition, when electrons are transported from the substrate to electron acceptors, the reductive and oxidative (redox) reactions occur, which drives the entire biological metabolism. Thus, the electron equivalent balances can be established to represent these 
redox reactions so as to obtain an insightful understanding of the metabolism during dark fermentation. The reports of the application of supervised machine learning via constructed artificial neuron networks (ANNs) via the feed backward propagation and one cross out validation approach in statistically analyzing the biohydrogen performance using lignocellulosic feedstock and rigorous analysis of electron equivalent balances during dark fermentation, to the best of our knowledge, has never been published before. These are the main objectives in this review paper.

\section{Approaches and Techniques}

In this work, artificial neuron networks (ANNs) were established in Python 2.7 (Python Software Foundation). For supervised learning, there are no consensuses in regarding to how many hidden layers should be utilized [32]. In this work, we employed the most widely used feed backward three layers to train data. During data training, the simplified one cross-out method was employed for cross validation. The simplified procedure can be summarized as following: (1) Set observation $i(1-n)$ from the data set being out and train the ANNs using the remaining data. (2) Computes the (mean square error) MSE and MARR (mean relative residual relation) as the following:

$$
\begin{gathered}
M S E \%=\frac{1}{N_{\text {sam }}} \sum_{j=1}^{N_{\text {sam }}}\left(r \mid i^{\text {sam }}-r_{i}^{\mathrm{cal}}\right)^{2} \times 100 \% \\
M A R R \%=\frac{1}{N_{\text {sam }}} \sum_{j=1}^{N_{\exp }}\left(\frac{\left|r_{i}^{\text {sam }}-r_{i}^{\text {cal }}\right|}{r_{i}^{\text {sam }}}\right) \times 100 \%
\end{gathered}
$$

where $N_{\text {sam }}$ is the number of sample data set, $r_{i}^{\text {sam }}$ and $r_{i}^{\text {cal }}$ are actual and calculated values, respectively. (3) Repeat step 1 until $i=1 \ldots$ n. (4) Average all responses from ANNs. (5) Repeat steps 1-4, twice. Once allowable accuracy reaches over 95\%, the established ANNs will generate prediction via designed matrix such as Box-Behnken design (BBD) and the central composite design (CCD). Finally, the established hybrid ANNs-response surface methodology (ANNs-RSM) with BBD design was evaluated using analysis of variance (ANOVA). The commercial Design Expert ${ }^{\circledR}$, Version 11 software package (Stat-Ease, Inc., 1300 Godward St NE, Suite 6400, Minneapolis, MN 55413 USA) was used for ANOVA.

\section{Dark Fermentation}

The hydrogen generation is achieved under the anaerobic condition through microbial oxidation of organic substrate and neutralization between the proton $\left(\mathrm{H}^{+}\right)$and electron $\left(\mathrm{e}^{-}\right)$. Because of different combinations of metallic active catalytic sites in the metal clusters of the hydrogenase, there are three types of hydrogenases involving the hydrogen reaction, which are $(\mathrm{FeFe}),(\mathrm{NiFe})$, and $(\mathrm{Fe})$ type hydrogenases [33-35]. While (Fe) type hydrogenases only exist in some specific methanogens, the (FeFe) type, catalyzing the formation of $\mathrm{H}_{2}$, and ( $\mathrm{NiFe}$ ) type, catalyzing the consumption of $\mathrm{H}_{2}$, are widely found in the anaerobic microbes [36-38].

Although the matrix of fermentation broth generated from different pretreatment approaches varies greatly [38], sugars in these different pre-treated lignocellulosic fermentation broths will be utilized via different metabolic pathways and these pathways will be eventually funneled into existing hydrogen generation metabolic pathways shown in Figure 2. 


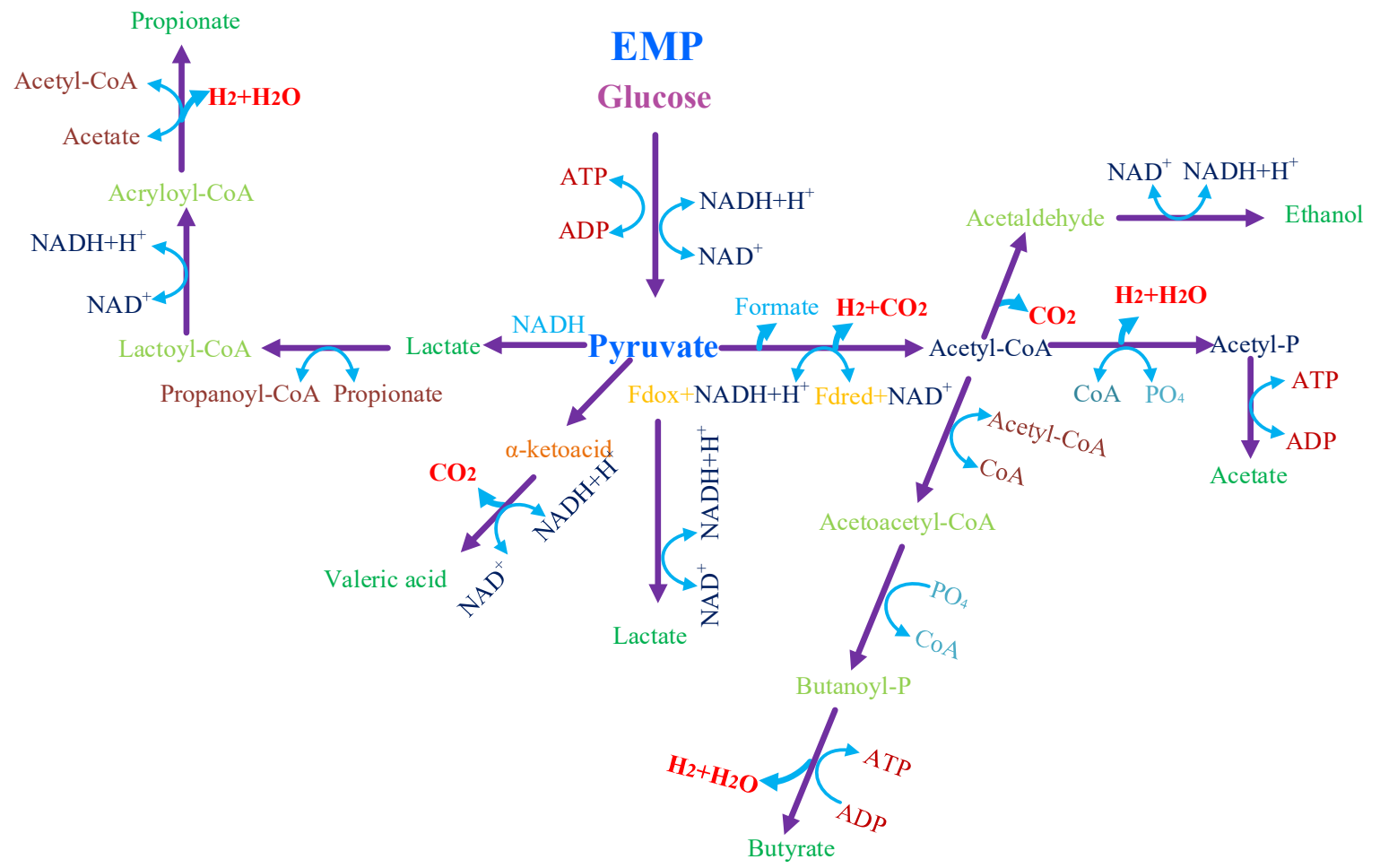

Figure 2. Schematic diagram of metabolic pathway for biohydrogen generation from pyruvate intermediate, and the figure was rearranged from Sun et al. [39].

Although alternative pathways such as the Entner-Doudoroff pathway exist, the formation of pyruvate via glycolysis is one of the most important and widely adopted pathways by the bacteria [40]. The delicate balances among different metabolic pathways are well maintained by intertwining the cell growth, substrate decomposition, and energy harvesting through a serious of coupled reductive and oxidative biological reactions (Figure 2). From a thermodynamic perspective, the theoretical hydrogen production per glucose reaches a $12\left(\mathrm{~mol} \cdot \mathrm{mol}^{-1}\right) \mathrm{H}_{2} /$ glucose ceiling value assuming glucose being completely consumed to produce hydrogen, as depicted in Equation (3):

$$
\mathrm{C}_{6} \mathrm{H}_{12} \mathrm{O}_{6}+6 \mathrm{H}_{2} \mathrm{O} \rightarrow 6 \mathrm{CO}_{2}+12 \mathrm{H}_{2}
$$

Although Equation (3) shows a large potential hydrogen yield, much energy has to be spent to convert substrate into biomass to maintain the metabolism within the microbes, which compromises the maximum theoretical hydrogen generation. Three main indicative metabolic products, namely acetate, propionate, and butyrate are directly related to the hydrogen generation process. From a stoichiometric perspective using one mole of glucose, the following metabolites (acetate, butyrate, and propionate) will be produced [41]:

$$
\begin{gathered}
\mathrm{C}_{6} \mathrm{H}_{12} \mathrm{O}_{6}+2 \mathrm{H}_{2} \mathrm{O} \stackrel{\text { Hydrogenase }}{\rightarrow} 2 \mathrm{CH}_{3} \mathrm{COOH}+2 \mathrm{CO}_{2}+4 \mathrm{H}_{2} \\
\mathrm{C}_{6} \mathrm{H}_{12} \mathrm{O}_{6} \stackrel{\text { Hydrogenase }}{\rightarrow} \mathrm{C}_{2} \mathrm{H}_{5} \mathrm{COOH}+2 \mathrm{CO}_{2}+3 \mathrm{H}_{2} \\
\mathrm{C}_{6} \mathrm{H}_{12} \mathrm{O}_{6}+2 \mathrm{H}_{2} \mathrm{O} \stackrel{\text { Hydrogenase }}{\rightarrow} \mathrm{C}_{3} \mathrm{H}_{7} \mathrm{COOH}+2 \mathrm{CO}_{2}+2 \mathrm{H}_{2}
\end{gathered}
$$

Broadly speaking, the phases of metabolites are divided into two categories: gaseous and liquid products. In regard to the liquid metabolites, the route of decomposition of glucose into acetate will lead to the largest hydrogen generation (Equation (4)) and this provides the guidance for the enhancement of $\mathrm{BioH}_{2}$ generation by adjusting or skewing metabolic pathways towards the formation of acetate 
during the DF [42]. In addition, other metabolites such as lactate, valeric acid, and ethanol (though their formations do not directly lead to hydrogen formation), are critical because of their participation in the redox reactions forming either the reduced nicotinamide adenine dinucleotide (NADH) or oxidized nicotinamide adenine dinucleotide (NAD+) and their subsequent ratio (NAD+/NADH) is a typical indicator of the activities of metabolism and health of the microbes [43]. In regard to gaseous metabolites, $\mathrm{H}_{2}$ is accompanied by the formation of $\mathrm{CO}_{2}$. Therefore, to better and comprehensive gauge the entire dark fermentation, the measurement of the key liquid metabolites (acetic acid, butyric acid, propionic acid, lactate, valeric acid, and ethanol) and gaseous metabolites $\left(\mathrm{H}_{2}\right.$ and $\left.\mathrm{CO}_{2}\right)$ are necessary.

\section{Pretreatment of Lignocellulosic Biomass and the Matrix of Substrate}

One of the most challenging aspects of renewable hydrogen generation technology, such as water electrolysis, to compete with current techniques based on fossil fuel, such as methane steam reforming (MSR), lies in its unfriendly cost. Exploring $\mathrm{BioH}_{2}$ production using renewable feedstock, such as biomass, presents a rosy prospect if the production of the feedstock is not competing with the production of food and arable land [44]. Table 1 summarizes different categories of bio-feedstock for renewable energy generation. There are three types of feedstock categories from biomass that can be used for bioenergy generation. Comparing with plant-based feedstock (second generation feedstock), microalgae are efficient photosynthetic organisms, have high growth rates and they do not need arable land and fresh water, since they can grow in brackish water, seawater and even wastewater [45]. In addition, the cell wall compositions mainly the cellulose, hemicellulose, and absence of lignin, requires much less harsh pretreatment comparing that with processing the lignocellulosic feedstock [46]. In order to achieve integrated utilization of microalgae compositions, such as proteins, lipids etc., mature solvent extraction process is often employed to selectively separate the high-valued compounds. However, this separation process is often wrestling with the limitations of harvesting, high-cost, non-volatile features, subsequently restricted back extraction, and unknown environmental impacts, which prevented its development at industrial scale [47]. Apart from fractionation, cultivation of microalgae and harvesting especially on the large scale is also facing thorny challenges, i.e., relative high cost, risk of contamination, and relatively low biomass productivities. The common economical approaches of algae cultivation include: open ponds (open system), tubular, modified photobioreactors (PBRs), flat panel PBRs (closed system), etc. [48]. The common harvesting microalgae includes: physical, chemical, biological, magnetic, and combined process, of which each one possesses its inherent pro and cons [49]. The likelihood of dark fermentative biohydrogen from microalgal culture lies with the fact that hydrogen is generated by heterotrophic satellite colonies thriving anaerobically within the microalgal biomass. Although, this processes are more related to anaerobic fermentative bacteria (e.g., Escherichia coli, Clostridium spp., Thermococcales spp, Rhodobacter spp., and Rhodopseudomonas spp.), certain microalgal species (e.g., Chlamydomonas sp., Chlorella sp., and Scenedesmus sp.) have been reported to convert organic substrate into hydrogen anaerobically [50]. Due to many appealing advantages, especially cost-effectiveness and availability of readily available industrial processes, efforts upon using the second generation feedstock have been made extensively both in industry and academia. Second-generation feedstock, which come from non-food crops and agricultural waste, indeed provides even bigger potential due to its large availabilities and some existing technologies that are readily mature to process the lignocellulosic precursors. In this work, to narrow the scope of discussions, we will further focus on the $\mathrm{BioH}_{2}$ production from lignocellulosic biomass as the feedstock. 
Table 1. Summary of different types of biomass as feedstock.

\begin{tabular}{|c|c|c|c|c|}
\hline $\begin{array}{c}\text { Types of } \\
\text { Feedstock }\end{array}$ & Substances & Examples & Advantages & Limitations \\
\hline $\begin{array}{c}\text { First } \\
\text { generation }\end{array}$ & Food crops & $\begin{array}{l}\text { Converting sugars } \\
\text { including: glucose, } \\
\text { xylose, lactose. } \\
\text { ucrose, maltose, etc. } \\
\text { - Starch, molasses, etc. }\end{array}$ & 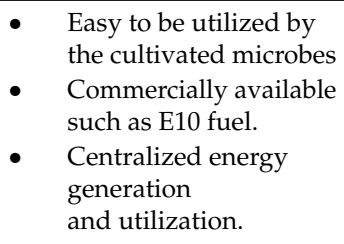 & $\begin{array}{l}\text { - } \quad \text { Competing with food } \\
\text { source and arable lands } \\
\text { - High cost }\end{array}$ \\
\hline $\begin{array}{c}\text { Second } \\
\text { generation }\end{array}$ & $\begin{array}{l}\text { Lignocellulosic } \\
\text { resources } \\
\text { (hemicellulose and } \\
\text { cellulose) }\end{array}$ & $\begin{array}{l}\text { Agricultural waste } \\
\text { including: corn } \\
\text { stover, wheat bran, } \\
\text { wheat straw, rice } \\
\text { straw, sweet sorghum } \\
\text { potato steam peels, } \\
\text { cassava stillage, } \\
\text { sugarcane bagasse, } \\
\text { and beer lees, } \\
\text { grass, etc. } \\
\text { Paper pulping: } \\
\text { pulping wastewater. } \\
\text { Forestry by-products: } \\
\text { saw dust, wood chip }\end{array}$ & $\begin{array}{ll}\text { - } & \text { Great abundance } \\
\text { - } & \text { Available for } \\
\text { - } & \text { Colid fermentation } \\
& \text { including } \\
\text { - } & \text { pretreatment cost) } \\
\text { Decentralized energy } \\
\text { generation } \\
\text { and utilization. }\end{array}$ & $\begin{array}{l}\text { - Inert to most microbes } \\
\text { for } \mathrm{BioH}_{2} \text { productions. } \\
\text { - } \quad \text { High cost of } \\
\text { necessary pretreatment } \\
\text { - } \\
\text { Detoxication process } \\
\text { required, such as } \\
\text { neutralization by adding } \\
\text { acid/base }\end{array}$ \\
\hline $\begin{array}{c}\text { Third } \\
\text { generation }\end{array}$ & $\begin{array}{l}\text { Sucrose-based, } \\
\text { Starch based, } \\
\text { Microalgae. }\end{array}$ & $\begin{array}{l}\text { - Sugar cane } \\
\text { and molasses. } \\
\text { Wheat, corn, barley, } \\
\text { sweet sorghum, } \\
\text { and sweet potato, } \\
\text { Microalgae }\end{array}$ & $\begin{array}{l}\text { - } \quad \text { Rapid growth rate, } \\
\text { Cultivability } \\
\text { without soil, } \\
\text { - } \quad \text { Simultaneously } \\
\text { green-house gas } \\
\text { capture, such as } \mathrm{CO}_{2} \text {. } \\
\text { - } \quad \text { Fast turn-around cycle } \\
\text { (1-10 days), } \\
\text { High contents of } \\
\text { carbohydrate and } \\
\text { lipids, less } \\
\text { harsh pretreatment. }\end{array}$ & $\begin{array}{l}\text { - } \quad \text { Early stage of the study } \\
\text { - } \quad \text { Potential inhibitors to the } \\
\text { subsequent fermentation }\end{array}$ \\
\hline
\end{tabular}

One of the main disadvantages of lignocellulosic biomass is the required pretreatment to achieve fermentative substrates. Table 2 summarizes the results of $\mathrm{BioH}_{2}$ production from different lignocellulosic biomass hydrolysates pretreated by different approaches, using different microbes. The matrix of hydrolysate (the substrates such as the concentrations of glucose, xylose, and the inhibitors such as acetate, furfural, and aromatic compounds) plays the most critical role in determining the effectiveness of $\mathrm{BioH}_{2}$ production once the microbial strains are chosen. In order to provide insightful understanding between the matrix of hydrolysate and $\mathrm{BioH}_{2}$ production (HY and HER), we employed a recently developed novel correlation algorithm using the established artificial neuron networks (ANNs) combined with Box-Behnken design (BBD) design [32]. The schematic diagram of the established ANNs using training data from the references in Table 2 is depicted in Figure 3. 
Table 2. Biohydrogen generation from lignocellulosic biomass.

\begin{tabular}{|c|c|c|c|c|c|c|c|c|}
\hline \multirow{2}{*}{ Microbes $^{+}$} & \multirow{2}{*}{ Biomass } & \multicolumn{4}{|c|}{$\begin{array}{l}\text { Composition after } \\
\text { Pretreatment } / g \cdot L^{-1}\end{array}$} & \multirow{2}{*}{$\begin{array}{c}\mathrm{HY} \\
\mathrm{mol} \cdot \mathrm{mol}^{-1}\end{array}$} & \multirow{2}{*}{$\begin{array}{c}\text { HER } \\
\mathrm{mmol} \cdot \mathrm{L}^{-1} \cdot \mathrm{h}^{-1}\end{array}$} & \multirow{2}{*}{ Reference } \\
\hline & & Glucose & Xylose & Acetate & $\operatorname{Inh} \ddagger$ & & & \\
\hline TT-W16 & CS & 2.1 & 9.0 & 1.5 & 0.5 & 2.24 & 4.9 & [51] \\
\hline AS & CS & 5.5 & 27 & $1.0 !$ & $0.1 !$ & 2.84 & 0.2 & [52] \\
\hline CB-AS1.209 & CS & 3.5 & 1 & $0.5 !$ & 0.5 & 1.09 & 1.4 & [53] \\
\hline MM & WS & $2 !$ & $4.2 !$ & $1.0 !$ & $0.6 !$ & 1.01 & 0.3 & [54] \\
\hline AS & WS & 1.2 & 1.1 & 0.7 & 0.5 & 2.81 & 0.9 & [55] \\
\hline CB-CGS5 & RS & 0.1 & 9.2 & 0.3 & 2.6 & 0.76 & 0.6 & [56] \\
\hline $\mathrm{CB}$ & SB & 11 & 11 & 2.5 & 0.1 & 1.73 & 1.6 & [57] \\
\hline $\mathrm{CS}^{*}$ & SS & 31 & 13 & 2.1 & 0.1 & 2.6 & 2.1 & [58] \\
\hline MM & SS & $2 !$ & $6 !$ & $1.1 !$ & $0.1 !$ & 2.1 & 0.4 & [59] \\
\hline $\mathrm{CS}^{*}$ & WS & 7 & 3 & 0.4 & 0.1 & 3.1 & 9.7 & [60] \\
\hline CS-8903 & SG & 1.8 & 1.5 & 1.1 & 0.1 & 1.6 & 0.2 & [61] \\
\hline TT-MJ1 & SB & 1.5 & 12 & 2.5 & 0.1 & 2.2 & 1.1 & [62] \\
\hline STDEV & & 8.53 & 7.36 & 0.81 & 0.71 & 0.78 & 2.77 & \\
\hline
\end{tabular}

† TT-W16: Thermoanaerobacterium thermosaccharolyticum W16, AS: activated sludge, CB: Clostridium butyricum AS1.209, MM: mixed microflora, CB-CGS5: Clostridium butyricum CGS5, CB: Clostridium butyricum, CS*: Caldicellulosiruptor saccharolyticus, CS-8903: Caldicellulosiruptor saccharolyticus DSM 8903, TT-MJ1: Thermoanaerobacterium thermosaccharolyticum MJ1. + CS: corn stover, WS: wheat straw, RS: rice straw, SB: sugarcane bagasse, SS: sweet sorghum, SG: switchgrass. ${ }^{\ddagger}$ Inh refers to the inhibitors other than acetate, such as furfural compounds, aromatic compounds. 'Estimate. STDEV: standard deviation.

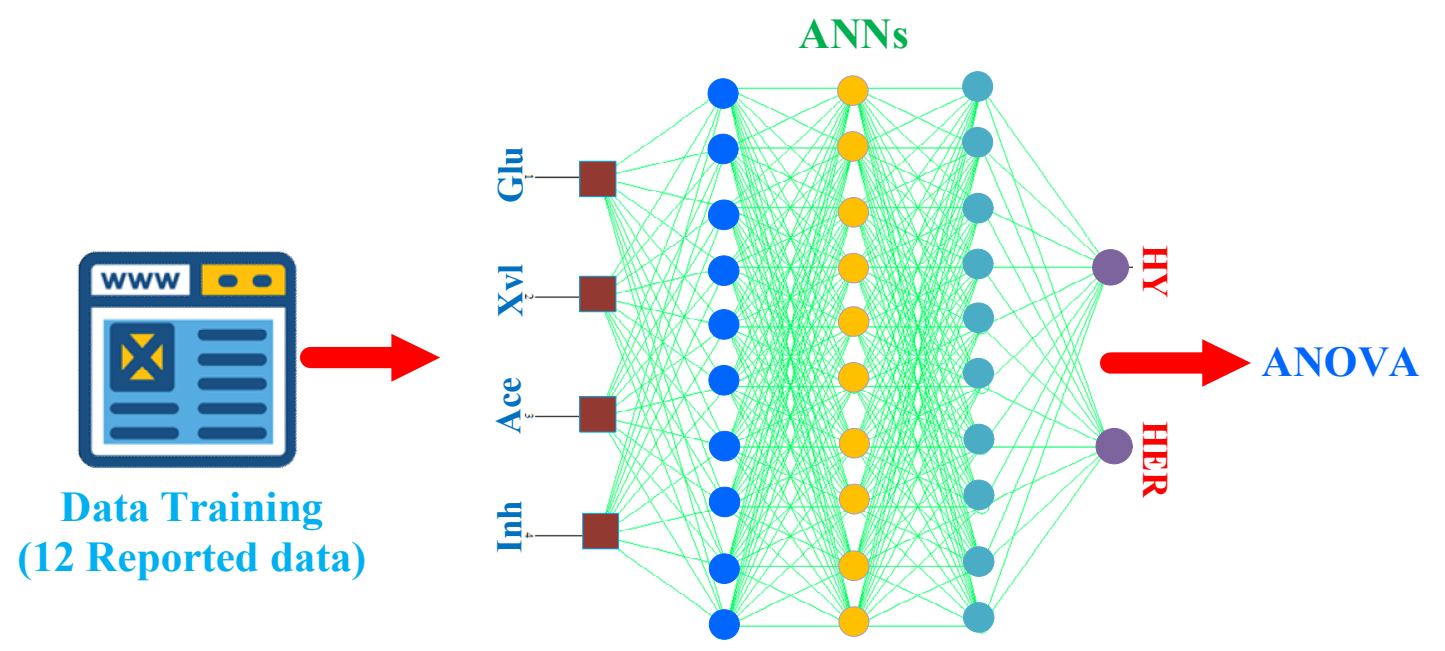

Figure 3. Schematic diagram using references in Table 2 as training data (three layers with 10 nodes), where Glu, Xyl, Ace, and Inh refer to glucose, xylose, acetate, and inhibitor, respectively. HY and HER are hydrogen yield and hydrogen evolution rate.

Because of its inherent features of fast converging and less computational time, together with equipped statistical analysis, this hybrid ANNs-RSM technique has presented very appealing application future. In this work, the references from Table 2 (in total 12 data sets) were utilized for data training. Four inputs (Glu, Xyl, Ace, and Inh), two outputs (HY and HER), together with three hidden layers (10 nodes in each layer) were used for the establishment of ANNs shown in Figure 3. Before training in ANNs, all training data were normalized using the maximum reported value from the references. For example, in the column 'Glucose' in Table 2, the maximum reported value for glucose is $31\left(\mathrm{~g} \cdot \mathrm{L}^{-1}\right)$, therefore, this value was used to normalize the entire column. The detailed established ANNs-RSM using BBD design can be found in Supplementary Table S1.

Among the investigated four variables (Glu, Xyl, Ace, and Inh), the binary combinations of Glu/Ace and Ace/Inh were found to be significant to HY and HER (Supplementary Table S2). Using the 
established ANNs-RSM approach, the quadratic correlations between the four investigated parameters and HY or HER can be constructed with statistical confidence over $95 \%$ as the following:

$$
Y=b_{0}+\sum_{i=1}^{4} b_{i} X_{i}+\sum_{i=1}^{4} b_{i i} X_{i}^{2}+\sum_{i<j, j=2}^{4} b_{i} X_{i} X_{j}
$$

where $Y$ is the predicted response (HY or HER), $b_{i}$ is the linear coefficient, $b_{0}$ is the intercept coefficient, $b_{i i}$ is the quadratic coefficient, $b_{i j}$ is the interaction term and $x_{i}$ and $x_{j}$ are the coded values of variables. The obtained coefficients of the established model are summarized in Supplementary Table S3. Within investigated range from the literature reports in Table 2, the 3D plots of the effects of the combined parameters towards the HY and HER are shown in Figure 4. There are optimal conditions for the optimum values of HY and HER. Figure 4a suggests that the maximum HY will be around $3 \mathrm{H}_{2}$ mol per mol of the substrate, if the glucose and acetate levels are maintained at 14 and 1.3 ( $\left.\mathrm{g} \cdot \mathrm{L}^{-1}\right)$ respectively. Similarly, the HY will be around $3\left(\mathrm{H}_{2} \mathrm{~mol} \cdot \mathrm{mol}^{-1}\right.$ substrate) if acetate and Inh are carefully managed at 1.4 and $1.6\left(\mathrm{~g} \cdot \mathrm{L}^{-1}\right)$, respectively. In regard to HER, to achieve the maximum HER, the glucose vs acetate and acetate vs. Inh needed to be around 14 vs. $1.3\left(\mathrm{~g} \cdot \mathrm{L}^{-1}\right)$ and $1.3 \mathrm{vs} .1 .1\left(\mathrm{~g} \cdot \mathrm{L}^{-1}\right)$, respectively. The validation results from one cross out approach is shown in Table S4. The calculated $M S E$ and MARR suggest a good training outcome.
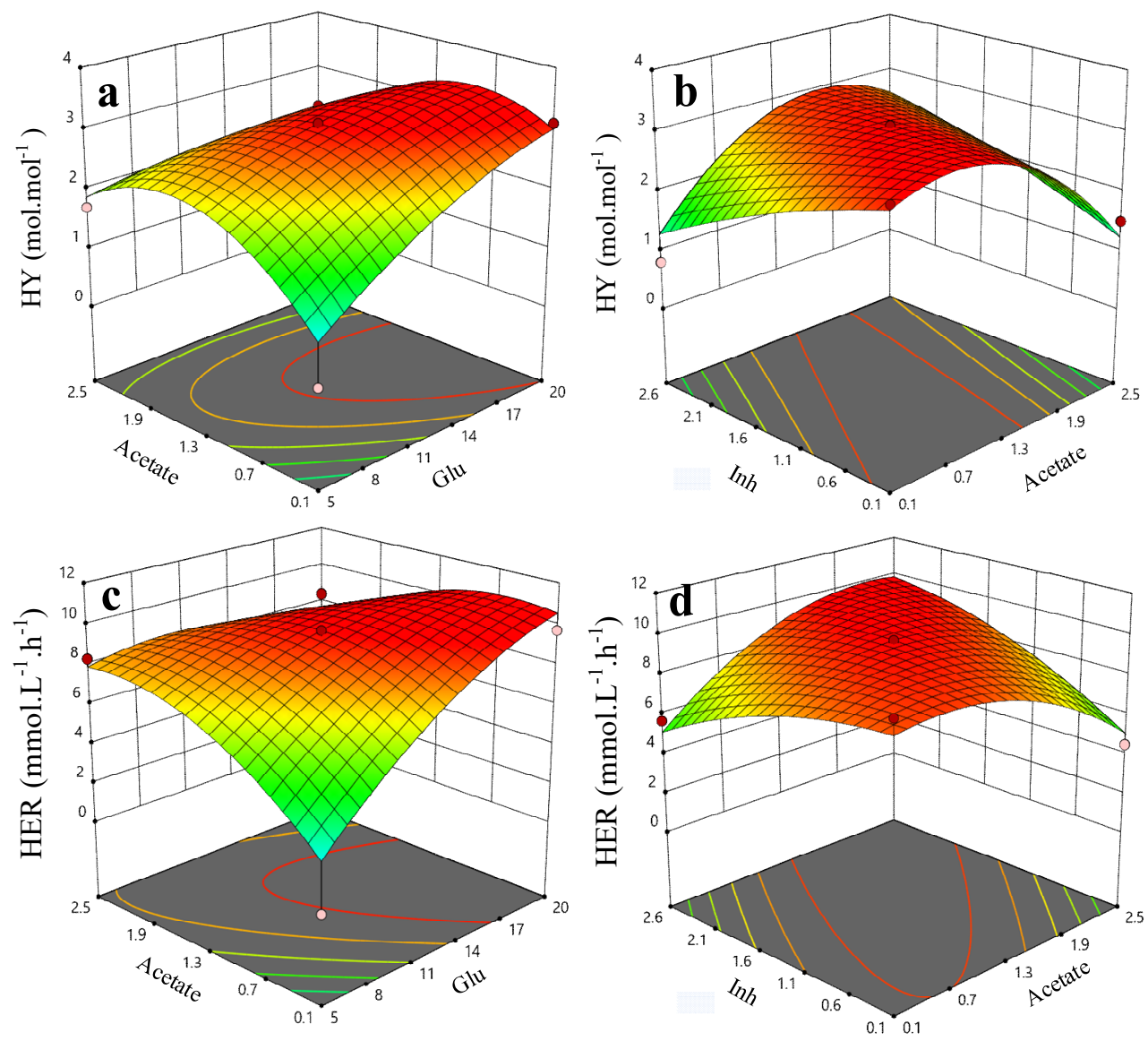

Figure 4. Effects of significant binary factors upon HY and HER across different literatures in Table 2, where (a) refers to HY vs the variations of acetate and glucose, (b) refers to HY vs the variations of inh and acetate, (c) refers to HER vs variations of acetate and glucose, (d) refers to HER vs variations of inh and acetate. 
Although the numbers of reports and the training data sets were very limited, it does provide obvious statistical correlations between the investigated four variables (Glu, Xyl, Ace, and Inh) and two outputs (HY and HER). This also clearly suggests that the careful manipulation of the compositions, especially the ratio of glucose to acetate and acetate to inhibitors (Glu/Ace/Inh optimal around 14:1.3:1) in the pretreated broth from lignocellulose biomass, are statistically vital in optimizing the HY and HER prior to DF. These results provide very useful guidance for future optimization of $\mathrm{BioH}_{2}$ production, let alone if great improvements could also be made from microbial strains via strain selection and genetic engineering.

\section{Electron-Equivalent Balances in $\mathrm{BioH}_{2}$ Productions}

In biological conversions, a substrate such as glucose is both the source of energy and the material used for the synthesis of cells and the products. Therefore, there is a balance between the fraction of total electrons present in the substrate being transferred to the electron acceptor by metabolic reactions to generate energy $\left(\mathrm{e}_{\mathrm{e}}\right)$ in the form of Adenosine triphosphate (ATPs) and the remaining fraction of total electrons being transferred to the biomass synthesis $\left(e_{s}\right)$. The sum of $e_{e}$ and $e_{s}$ is 1.0 as seen in the following [39]:

$$
\mathrm{e}_{\mathrm{e}}+\mathrm{e}_{\mathrm{s}}=1
$$

The oxidative and reductive reactions are two half-reactions together representing the net reactions. The fraction of electrons used for energy generation $\left(e_{e}\right)$ and biomass synthesis $\left(e_{s}\right)$ need to be known in balancing microbial reactions and the following equations will hold [41]:

$$
\begin{aligned}
& R_{e}=R_{a}+R_{d} \\
& R_{s}=R_{c}+R_{d}
\end{aligned}
$$

where $R_{e}$ and $R_{s}$ refer to the net-generation of energy and biomass synthesis, respectively. $R_{a}, R_{d}$, and $R_{c}$ refer to the electron acceptor, donor and cell synthesis (electron acceptor) half-reactions, respectively, which leads to the fractional electron utilization expression as the following:

$$
R_{\text {overall }}=\mathrm{e}_{\mathrm{e}}\left(R_{a}+R_{d}\right)+\mathrm{e}_{\mathrm{s}}\left(R_{c}+R_{d}\right)
$$

By coupling Equations (9) and (11):

$$
R_{\text {overall }}=\mathrm{e}_{\mathrm{e}} R_{a}+\mathrm{e}_{\mathrm{s}} R_{c}+R_{d}
$$

We will get the electron-equivalent $\left(\mathrm{e}^{-} \mathrm{eq}\right)$ balance as the following:

$$
\mathrm{e}^{-}\left(\text {glucose }_{i}\right)=\mathrm{e}^{-}\left(\text {glucose }_{f}\right)+\mathrm{e}^{-}(S M P)+\mathrm{e}^{-}(\text {biomass })+\mathrm{e}^{-}\left(H_{2}\right)
$$

where $\mathrm{e}^{-}\left(\right.$glucose $\left._{i}\right)$ is the $\mathrm{e}^{-}$eq balance of the initial glucose, $\mathrm{e}^{-}\left(\right.$glucose $\left._{f}\right)$ is the $\mathrm{e}^{-}$eq balance of the residue glucose, $\mathrm{e}^{-}(S M P)$ is the $\mathrm{e}^{-}$eq balance of soluble metabolic product, and $\mathrm{e}^{-}\left(H_{2}\right)$ is the $\mathrm{e}^{-}$ eq balance of the hydrogen formation. The empirical formula for bacteria cells is often assumed to be $\mathrm{C}_{5} \mathrm{H}_{7} \mathrm{O}_{2} \mathrm{~N}$, which slightly varies with the type of microbes and cultivation media. On the basis of one mole, the quantities of electrons in the $\mathrm{e}^{-}$eq balance with its corresponding compounds are summarized as the following: $\mathrm{C}_{5} \mathrm{H}_{7} \mathrm{O}_{2} \mathrm{~N}=20 \mathrm{e}^{-}$eq, acetic acid $=8 \mathrm{e}^{-}$eq, butyric acid $=20 \mathrm{e}^{-}$eq, propionate $=14 \mathrm{e}^{-}$eq lactate $=12 \mathrm{e}^{-}$eq and $\mathrm{H}_{2}=2 \mathrm{e}^{-}$Equation By incorporating the above quantities, the established stoichiometric equations of the electron donor-acceptor half-reactions for different compounds are expanded as the following [63]:

Glucose:

$$
(1 / 24) \mathrm{C}_{6} \mathrm{H}_{12} \mathrm{O}_{6}+(1 / 4) \mathrm{H}_{2} \mathrm{O} \rightarrow(1 / 4) \mathrm{CO}_{2}+\mathrm{H}^{+}+\mathrm{e}^{-}
$$


Acetic acid:

$$
(1 / 8) \mathrm{CO}_{2}+(1 / 8) \mathrm{HCO}_{3}^{-}+\mathrm{H}^{+}+\mathrm{e}^{-} \rightarrow(1 / 8) \mathrm{CH}_{3} \mathrm{COO}^{-}+(3 / 8) \mathrm{H}_{2} \mathrm{O}
$$

Butyric acid:

$$
(1 / 5) \mathrm{CO}_{2}+(1 / 20) \mathrm{HCO}_{3}^{-}+\mathrm{H}^{+}+\mathrm{e}^{-} \rightarrow(1 / 20) \mathrm{CH}_{3} \mathrm{CH}_{2} \mathrm{CH}_{2} \mathrm{COO}^{-}+(7 / 20) \mathrm{H}_{2} \mathrm{O}
$$

Propionic acid:

$$
(1 / 7) \mathrm{CO}_{2}+(1 / 14) \mathrm{HCO}_{3}^{-}+\mathrm{H}^{+}+\mathrm{e}^{-} \rightarrow(1 / 14) \mathrm{CH}_{3} \mathrm{CH}_{2} \mathrm{COO}^{-}+(5 / 14) \mathrm{H}_{2} \mathrm{O}
$$

Biomass:

$$
(1 / 5) \mathrm{CO}_{2}+(1 / 20) \mathrm{HCO}_{3}^{-}+(1 / 20) \mathrm{NH}_{4}^{+}+\mathrm{H}^{+}+\mathrm{e}^{-} \rightarrow(1 / 20) \mathrm{C}_{5} \mathrm{H}_{7} \mathrm{O}_{2} \mathrm{~N}+(9 / 20) \mathrm{H}_{2} \mathrm{O}
$$

Lactate:

$$
(1 / 12) \mathrm{CO}_{2}+(1 / 12) \mathrm{HCO}_{3}^{-}+\mathrm{H}^{+}+\mathrm{e}^{-} \rightarrow(1 / 12) \mathrm{C}_{3} \mathrm{H}_{5} \mathrm{O}_{3}^{-}+(2 / 12) \mathrm{H}_{2} \mathrm{O}
$$

Hydrogen formation:

$$
\mathrm{H}^{+}+\mathrm{e}^{-} \rightarrow(1 / 2) \mathrm{H}_{2}
$$

With the detailed characterization of fermentation broth of the above liquid and gaseous metabolites on time on stream (TOS), the dynamic variations of complicated metabolisms are quantitatively gauged and monitored during the DF. Due to the limited numbers of reports with detailed characterizations of the distributions of electron sinks during DF, we only summarize some recent research works with available data of detailed metabolism during DF in Table 3. In regard to comparisons of $\mathrm{BioH}_{2}$ performances across different reports, the challenges such as failure or omission of complete mass balance during DF still remain. The HY versus HER among the literature reports are summarized and compared in Figure 5.

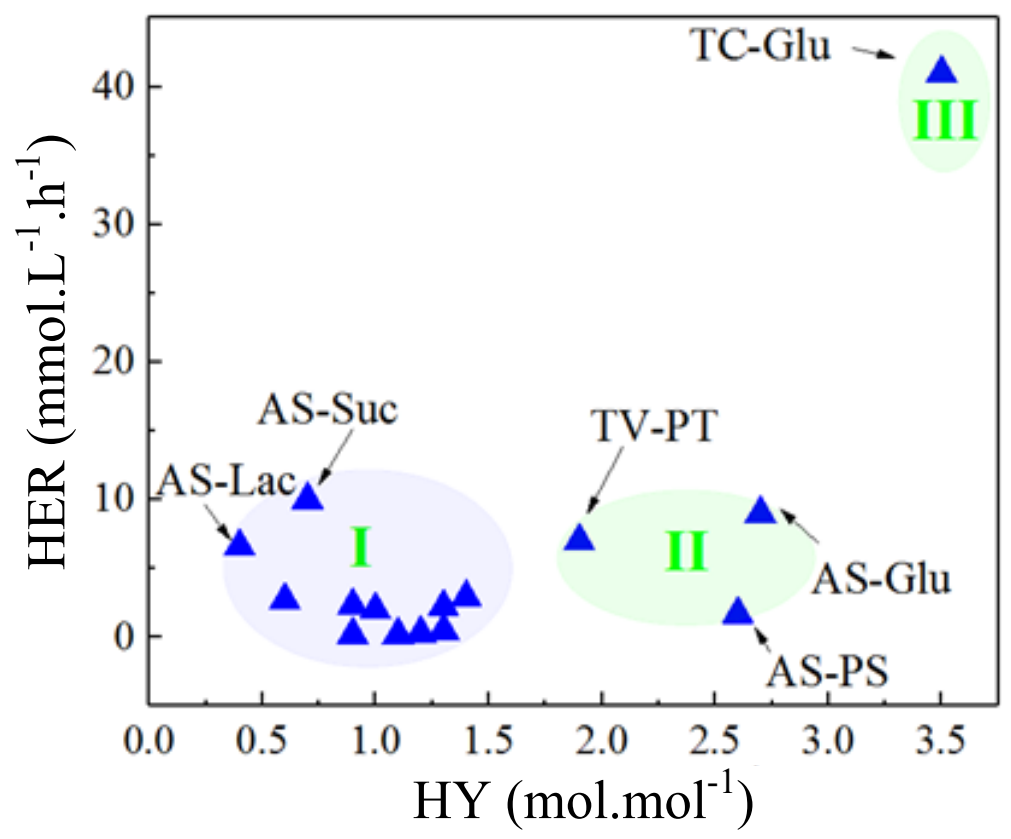

Figure 5. Data illustrating of the hydrogen yield (HY) versus HER over the literature reports from Table 3. 
Table 3. Stoichiometry variation by the effects of using different substrates.

\begin{tabular}{|c|c|c|c|c|c|c|c|c|c|}
\hline Substrate & $\begin{array}{c}\text { Biomass } \\
/ \%\end{array}$ & $\begin{array}{c}\text { Acetate } \\
/ \%\end{array}$ & $\begin{array}{c}\text { Butyrate } \\
/ \%\end{array}$ & $\begin{array}{c}\text { Propionate } \\
/ \%\end{array}$ & $\begin{array}{c}\mathrm{HY} \\
\mathrm{mol} \cdot \mathrm{mol}^{-1}\end{array}$ & $\begin{array}{c}\text { HER } \\
\mathrm{mmol}^{-} \mathrm{L}^{-1} \cdot \mathrm{h}^{-1}\end{array}$ & Microbes & $\begin{array}{c}\text { Operation } \\
/-\end{array}$ & Reference \\
\hline Cornstover/ & 22.6 & 22.1 & 31.5 & 15.5 & 0.9 & 0.2 & $\mathrm{CB}$ & Bat & [39] \\
\hline Cornstover+NP Ni & 21.9 & 21.9 & 31.6 & 15.3 & 1.2 & 0.3 & $\mathrm{CB}$ & Bat & [39] \\
\hline Organic wastewater & 2 & 56.5 & 24.4 & 9.1 & 1.3 & 0.5 & AS & Cont & [64] \\
\hline Sugarcane & 17.3 & 22.1 & 47.7 & 7.1 & 0.9 & 2.3 & $\mathrm{CL}$ & Bat & {$[65]$} \\
\hline Sugarcane $+\mathrm{Fe}^{2+}$ & 13.5 & 23.3 & 47.5 & 2.1 & 1.3 & 2.2 & $\mathrm{CL}$ & Bat & {$[65]$} \\
\hline Pistia stratiotes & 25.3 & 25.9 & 19.2 & 2.2 & 2.6 & 1.7 & AS & Bat & {$[66]$} \\
\hline Glucose & 1 & 37.8 & 3.4 & 17.9 & 2.7 & 9 & AS & Bat & {$[67]$} \\
\hline Xylose & 5.6 & 18.7 & - & - & 1.1 & 0.2 & $\mathrm{KO}$ & Bat & [68] \\
\hline Sucrose & 9.1 & 47.6 & 41.2 & 3.5 & 0.7 & 10 & AS & Cont & [69] \\
\hline SW-CWP & 1.2 & 11.8 & 39.9 & $27.3 *$ & 1.4 & 2.9 & AS & Cont & [70] \\
\hline Glucose & 6.8 & 15 & 10 & 3.5 & 1.0 & 2 & $\mathrm{CT}$ & Cont & [71] \\
\hline Glycerol & 8.3 & 6 & 42.5 & $1.8^{\#}$ & 0.6 & 2.7 & $\mathrm{CP}$ & Bat & [72] \\
\hline Glucose & 1 & 47.3 & - & - & 3.5 & 41 & $\mathrm{TC}$ & Bat & [73] \\
\hline Lac/Ace & 7.2 & 17.2 & 68.8 & - & 0.4 & 6.6 & AS & Cont & [74] \\
\hline TV & 5.8 & 16.1 & 54.4 & $11.9^{\#}$ & 1.9 & 7 & PT & Cont & [75] \\
\hline
\end{tabular}

* lactate. ${ }^{\#}$ succinate. NP Ni: nanoparticle Ni, SW-SWP: synthetic wastewater containing cheese whey powder, Lac: lactate, Ace: acetate, TV: Tequila vinasse. CB: Clostridium butyricum, CL: Clostridium spp, AS: activated sludge, KO: Klebsiella oxytoca, CT: Clostridium tyrobutyricum, CP: Clostridium pasteurianum, TC: Thermobrachium celere, PT: PTA-124566. Bat: batch, Cont: continuous. 
The $\mathrm{BioH}_{2}$ performances over the averaged value were annotated for easiness of discussion (Figure 5). There are three different regions of the $\mathrm{BioH}_{2}$ yield (HY) versus rates (HER). In our recent work, the performances of $\mathrm{BioH}_{2}$ yield (HY) versus rates (HER) from DF among different literatures were rigorously compared [2]. It was found that the averaged value of $\mathrm{HY}=1 \mathrm{~mol} \cdot \mathrm{mol}^{-1}$ for $\mathrm{HER}=0.3$ $\left(\right.$ mol. $\left.L^{-1} \cdot h^{-1}\right)$ generally agrees well with most of the reported values with the exception of two reports $[67,69]$, of which HER values reach 6 and $10\left(\mathrm{~mol} \cdot \mathrm{L}^{-1} \cdot \mathrm{h}^{-1}\right)$, respectively. For these two relative higher HER in the region (I), they both employed a mixed culture of microbes isolated from activated sludge and the substrates used for cultivation were sucrose and lactate, respectively. The appreciable difference of reported works in the region (II) lies in the obvious increased HY though HER also increase slightly compared with the averaged value in the region (I). Among these three reports, using glucose as substrate by mixed culture presents the best performance. There is one exceptional high value for both HY and HER ( $3.5 \mathrm{~mol} \cdot \mathrm{mol}^{-1}$ and $40 \mathrm{~mol} \cdot \mathrm{L}^{-1} \cdot \mathrm{h}^{-1}$, respectively) using glucose as substrate with a pure culture of Thermobrachium celere (TC) strain (region III). Possible reasons not only derive from the inherent metabolic features of microbe during DF but can also be potentially attributed to the types of operations such as continuous operation at the optimized conditions.

The distributions of electron sinks in the major metabolites across different works using different microbial strains are summarized and shown in Figure 6a (HY) and Figure 6b (HER). For the convenience of comparisons, three top high values by considering both HY and HER (for HY using a red square and HER using a red circle) were highlighted. To yield higher HY and HER, the relatively larger electron sinks in acetate are generally observed except using Klebsiella oxytoca $(\mathrm{KO})$ microbial strains that lead to a low HER possibly due to the direct employment of xylose that mainly relies on the formate cleavage metabolic pathway [68]. This agrees with the pyruvate metabolism during fermentation on the stoichiometric basis. In regards to the biomass synthesis, the correlations between the electron sinks and $\mathrm{BioH}_{2}$ performances present discrepancy. Since the microbial cell is the host for reactions including hydrogen generation, the metabolism for $\mathrm{BioH}_{2}$ generation needed to be compromised with biosynthesis metabolism. This agrees well with the literature reports obtained from DF using sugarcane hydrolysate as substrate in batch operation, with the electron sinks for acetate (36\%) and biomass (35\%) being similar to each other. On the other hand, larger HY and HER are also observed in some reports where electron sinks in the biomass only takes about $1-2 \%$ of the entire liquid metabolite (Figure 6a,b). This discrepancy most likely stems from the approaches of operations between batch and continuous operations (Chemostat), of which the batch operation will experience a continuous biomass increases after inoculation while the Chemostat will maintain a dynamic steady balance for biomass after start-up. Although the numbers of literature reports for electron-equivalent balance comparison are limited, it potentially suggests that the continuous operations tend to produce better $\mathrm{BioH}_{2}$ performances if all other conditions are maintained the same. In addition, the distributions of electron-equivalent balances also indirectly reflect the activities of different genus of bacteria if a mixed culture is employed during the fermentation. Depending on the substrate used during fermentation, the activities of different genus in the microbial ecology vary accordingly. The hexose especially glucose is one of the most easily utilized carbon sources during fermentation across all different types of microbes [76]. As for pentose, when acetate is produced as a by-product, xylose can be converted to $\mathrm{H}_{2}$. While a wide range of bacteria has the capability of utilizing hexose to produce $\mathrm{H}_{2}$, only a few pentose-fermenting microorganisms have been identified [68,77]. For example, it has been found that the Caldicellulosiruptor saccharolyticus could utilize the substrate (xylose and glucose) simultaneously for cells growth and $\mathrm{H}_{2}$ production and the consumption efficiency was higher than xylose as a sole carbon source $[78,79]$. Apart from conventional hexose such as glucose, other substrates such as lactate, acetate can be also utilized as the carbon source for $\mathrm{BioH}_{2}$ generation by the species such as Clostridium beijerinckii, Clostridium butyricum, and Clostridium tyrobutyricum and these strains are found to be associated with the activities of butyrate metabolism from pyruvate [80-83]. To sum up, the level of acetate in metabolites is surely an indicator of relative higher $\mathrm{BioH}_{2}$ yield (HY) and generation rate (HER). In batch operation, the electron sinks in biomass synthesis also needs to be maintained at a 
relatively higher level (similar level to that in acetate sink). The continuous operations tend to yield the larger HY and HER albeit the electron sinks in biomass synthesis is maintained at a low level.

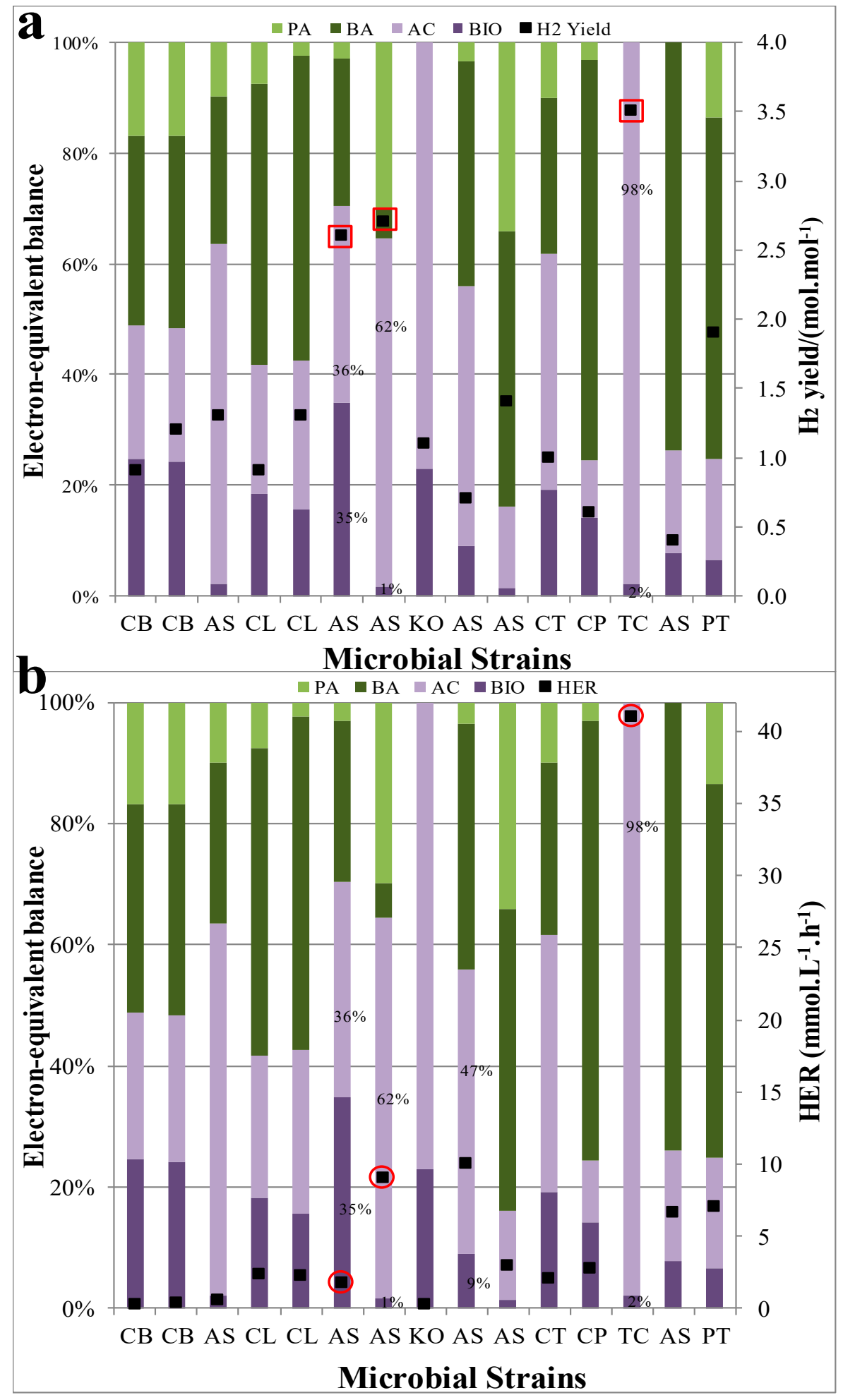

Figure 6. Distributions of electron equivalent balance across literature reports in Table 3, (a) HY vs different microbial strains and (b) HER vs different microbial strains, where horizontal axis refers to the microbes used during cultivation. Note: the electron sinks fractions in the major liquid metabolites were normalized in the electron-equivalent balance. Square refers to HY and circle refers to HER. 


\section{Results Comparison among Different Process Intensifications}

The ultimate goal in $\mathrm{BioH}_{2}$ production research is to enhance the hydrogen production so as to be as cost-effective as possible. For process intensification, the approaches such as pure culture, continuous operation, consolidated saccharification and fermentation, chemical additions, are optimization avenues. In this work, for convenience of discussions, the comparisons were divided into the following five categories, namely pure culture (PC) [73,84-94], chemical additions (CA) [2,39, 76,95-97], continuous operation with mixed culture (COMC) [98-102], batch operation with mixed culture (BOMC) [103-108] and consolidated saccharification and fermentation (CSF) [18,31,61,109-111], respectively. For quantitative comparison of hydrogen yield across different literatures, the necessary Carbon-molar-based mass balance for DF is pivotal and necessary. Because of the omission of mass balances during DF in some reported works, we only adopted those literature reports with complete mass balance and rate expressions. Within each category, all the collected $\mathrm{BioH}_{2}(\mathrm{HY}$ and $\mathrm{HER})$ were averaged and corresponding standard deviations were calculated at the following:

$$
\bar{x}=\sqrt{\frac{1}{N-1} \sum_{i=1}^{N}\left(x_{i}-\bar{x}\right)^{2}}
$$

where $N$ represents the numbers of references, $\bar{x}$ represents the averaged values, $x_{i}$ refers to the specific one reported value. The comparison of results across different literatures is depicted in Figure 7. Apparently, one of the most prominent factors that determine the performance for $\mathrm{BioH}_{2}$ production is the type of microbial strain. The selection of microbial strains with exceptional higher capacity in hydrogen productions is the most appreciable approach in enhancing $\mathrm{BioH}_{2}$ production. Clearly, with the isolation of pure strain potentially compounded with genetic engineering, the recombined bacteria with relative stable plasmid that possesses appealing features of larger hydrogen production will be an attractive approach for future $\mathrm{BioH}_{2}$ production research and development. On the other hand, more efforts should be focused on the issues of improving the stability of genetic expression, biosecurity, and the cost-effectiveness of cultivation of genetic engineered bacteria. Apart from microbial strains, chemical additions such as using synergistic factor like biochars and nanoparticles, are found to effectively improve $\mathrm{BioH}_{2}$ production. Besides to chemical addition, continuous operation with mixed culture is also found to be effective in enhancing $\mathrm{BioH}_{2}$ production. Obviously, the batch operation and simultaneous saccharification and fermentation, especially using pretreated lignocellulosic biomass as fermentation broth still present quite low ceiling values for $\mathrm{BioH}_{2}$ productions. The effective enhancement of $\mathrm{BioH}_{2}$ production not only lies in manipulating the optimal compositions in the pretreated solutions (maximizing the reducible sugars especially the glucose and minimizing toxic compounds especially the acetate) prior to the fermentation, but also relies on the high performance fermentation operations. From the above comparisons, a more realistic enhanced process approach might be incorporating all the appealing features from different types of process intensification approaches discussed above into an integrated bioprocess for hydrogen fermentation. 


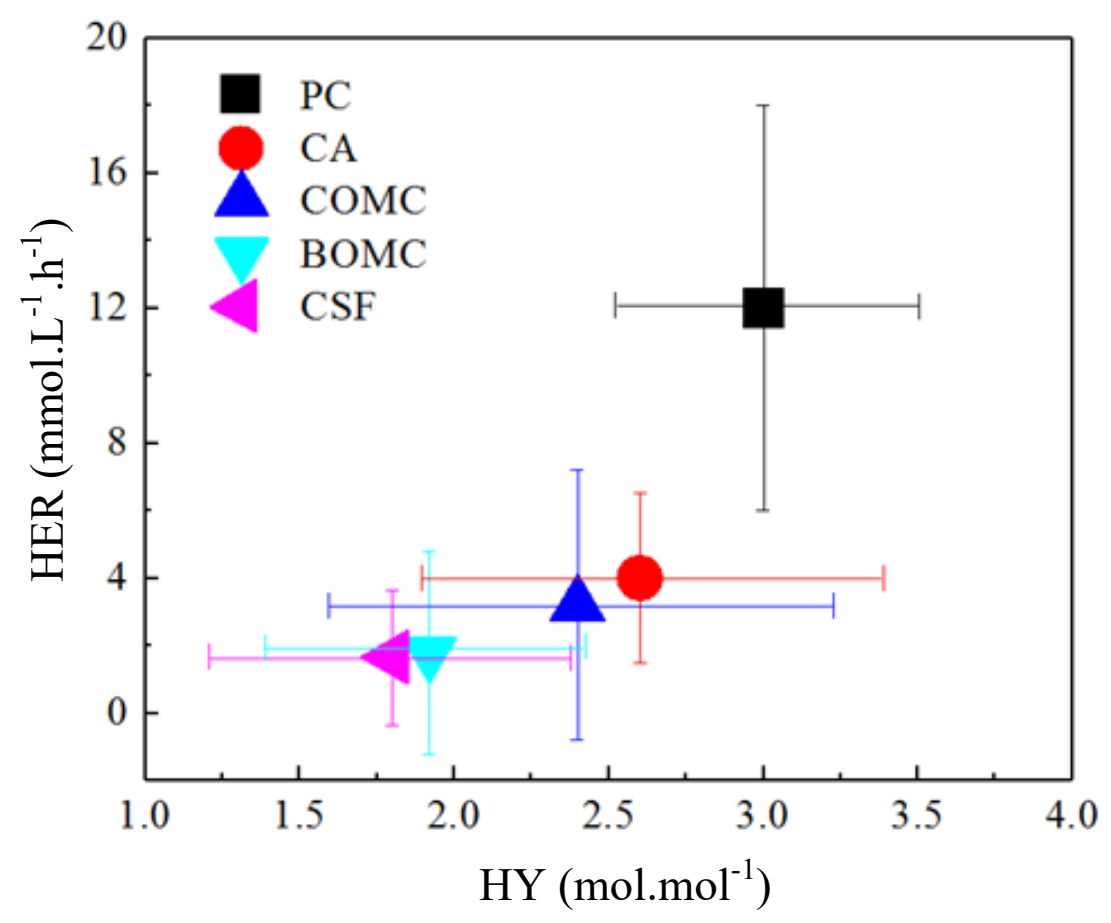

Figure 7. Comparisons of $\mathrm{BioH}_{2}$ performances (HY versus HER) across different categories using biomass, where PC refers to pure culture, CA refers to chemical addition, COMC refers to continuous operation with mixed culture, BOMC refers to batch operation with mixed culture, CSF refers to consolidated saccharification and fermentation.

The inherent limitations i.e., finite reserves which are located in geopolitical sensitive region, volatile prices, not renewable, greenhouse gas emissions, etc. that limit the application of fossil fuels for sustainable development meeting future energy and chemical needs [112-114]. Currently, more and more countries have realized the importance of shifting the paradigm of the development of human society from the primitive concept of "take, make, and dispose of" to "reuse and recovery" of resources to achieve "healthy environment-healthy human being" and "socio-economic prosperity" [115]. From an energy cascade utilization and material recycling and reused perspective, the utilization of second-generation biomass feedstock (lignocellulosic biomass) might need to follow a more delicate pretreatment process to fractionate three main compositions (cellulose, hemicellulose, and lignin) first, then followed by the subsequent conversion [116-118]. Due to inherent resilient features of lignocellulose, the pretreatment process is one of the core processing step for lignocellulose conversion. The recent works deploying different types of pretreatment are summarized and commented (merits and drawbacks) in Table 4. 
Table 4. Merits and drawbacks of different pretreatment for lignocellulosic biomass.

\begin{tabular}{|c|c|c|c|}
\hline $\begin{array}{c}\text { Types of } \\
\text { Pretreatment }\end{array}$ & Merits & Drawbacks & References \\
\hline $\begin{array}{l}\text { Physical } \\
\text { Millings }\end{array}$ & $\begin{array}{l}\text { Effective downsizing the particle } \\
\text { size and degree } \\
\text { of polymerization } \\
\text { Relative less environmental } \\
\text { impact and } \\
\text { chemical consumptions }\end{array}$ & $\begin{array}{ll}\text { - } & \text { High power consumption } \\
\text { - } & \text { Limited } \\
\text { enzymatic digestibility. } \\
\text { - } & \text { High CAPEX and OPEX }\end{array}$ & [119] \\
\hline Microwave & $\begin{array}{ll}\text { - } & \text { Simple operation } \\
\text { - } & \text { Fast heating rate } \\
\text { - } & \text { Low energy consumption } \\
\text { - } & \text { Specific destructive to } \\
& \text { crystallization of cellulose }\end{array}$ & $\begin{array}{ll}\text { - } & \text { Cost unfriendly } \\
\text { - } & \text { Difficult to scale up } \\
\text { - } & \text { Ineffective delignification } \\
\text { - } & \text { Formation of inhibitors }\end{array}$ & [120] \\
\hline $\begin{array}{l}\text { Chemical } \\
\text { Acid }\end{array}$ & $\begin{array}{ll}\text { - } & \text { Fast liberation of } \\
\text { - } & \text { Meducible sugars } \\
\text { - } & \text { Cost effectiveness } \\
\text { - } & \text { Low concentration } \\
\text { - } & \text { Maturation }\end{array}$ & $\begin{array}{ll}\text { - } & \text { Generation of inhibitors } \\
\text { - } & \text { Recovery of acidic catalyst } \\
\text { - } & \text { Detoxification process } \\
\text { Environmental impact }\end{array}$ & [116] \\
\hline Alkaline & $\begin{array}{ll}\text { - } & \text { Reasonable low CAPEX } \\
\text { - } & \text { Commercial available } \\
\text { - } & \text { Industrial mature } \\
\text { - } & \text { Highly delignification }\end{array}$ & $\begin{array}{ll}\text { - } & \text { Black liquor recovery } \\
\text { - } & \text { Scale dependent } \\
\text { - } & \text { Silicate colloids }\end{array}$ & [118] \\
\hline Ionic liquid & $\begin{array}{ll}\text { - } & \text { Environmental compatibility } \\
\text { - } & \text { Low operational pressure } \\
\text { - } & \text { No release of toxic or } \\
& \text { explosive gases } \\
\text { - } & \text { Thermal stability }\end{array}$ & $\begin{array}{ll}\text { - } & \text { High temperature } \\
\text { - } & \text { Long residence time } \\
\text { - } & \text { Cost unfriendly } \\
\text { - } & \text { Poor delignification } \\
\text { - } & \text { Recovery of ionic liquid }\end{array}$ & [121] \\
\hline Organosolv & $\begin{array}{ll}\text { - } & \text { Low temperature and pressure } \\
\text { - } & \text { Low cellulose lost } \\
\text { - } & \text { Formation of less } \\
\text { - } & \text { destructive lignin } \\
\text { Effective delignification }\end{array}$ & $\begin{array}{ll}\text { - } & \text { High lignin dependent } \\
\text { - } & \text { High CAPEX } \\
\text { - } & \text { Solvent recovery } \\
\text { - } & \text { Inhibitor generation }\end{array}$ & [122] \\
\hline Ozonolysis & $\begin{array}{l}\text { - } \quad \text { Low inhibitors generation } \\
\text { - } \quad \text { Ambient operational condition }\end{array}$ & $\begin{array}{ll}- & \text { Flammability of ozone } \\
- & \text { High CAPEX for ozone } \\
\text { generation onsite }\end{array}$ & [123] \\
\hline $\begin{array}{c}\text { Steam } \\
\text { explosion }\end{array}$ & $\begin{array}{ll}\text { - } & \text { Less toxic inhibitors } \\
\text { - } & \text { No need for size reduction } \\
\text { - } & \text { Higher yield for glucose } \\
\text { and hemicellulose } \\
\text { - } & \text { Short residence time }\end{array}$ & $\begin{array}{ll}\text { - } & \text { High CAPEX } \\
\text { - } & \text { Hard to scale up } \\
\text { - } & \text { Immature industrial scale } \\
\text { - } & \text { Less destructive } \\
& \text { to hemicellulose } \\
\text { - } & \text { Poor delignification }\end{array}$ & [124] \\
\hline $\begin{array}{l}\text { Biological } \\
\text { Enzymatic }\end{array}$ & $\begin{array}{ll}\text { - } & \text { Selective delignification } \\
\text { - } & \text { Less inhibitors } \\
\text { - } & \text { Simple downstream process } \\
\text { - } & \text { No need for chemical recovery }\end{array}$ & $\begin{array}{ll}\text { - } & \text { Long residence time } \\
\text { - } & \text { High cost for } \\
\text { enzyme production } \\
\text { - } & \text { Low downstream yield } \\
\text { - } & \text { Instability and deactivation } \\
\text { of enzyme }\end{array}$ & [125] \\
\hline
\end{tabular}


Table 4. Cont.

\begin{tabular}{|c|c|c|c|}
\hline $\begin{array}{c}\text { Types of } \\
\text { Pretreatment }\end{array}$ & Merits & Drawbacks & References \\
\hline Fungal & $\begin{array}{ll}\text { - } & \text { High efficiency and } \\
\text { - } & \text { downstream yield } \\
\text { - } & \text { Low energy consumption } \\
\text { - } & \text { No need for chemical recovery } \\
\text { - } & \text { Short downstream process }\end{array}$ & $\begin{array}{ll}\text { - } & \text { Commercial immature } \\
\text { - } & \text { Long treatment time } \\
\text { - } & \text { Compromise by } \\
& \text { carbohydrate lost } \\
\text { - } & \text { Low downstream yield } \\
\text { - } & \text { Instability during cultivation } \\
\text { - } & \text { Hard to industrial scale up }\end{array}$ & [126] \\
\hline $\begin{array}{l}\text { Microbial } \\
\text { consortium }\end{array}$ & $\begin{array}{ll}\text { - } & \text { Relative shorter treatment time } \\
\text { - } & \text { Increased enzymatic accessibility } \\
\text { - } & \text { Enhanced productivity }\end{array}$ & $\begin{array}{ll}\text { - } & \text { Operational } \\
\text { condition sensitive } \\
\text { - } & \text { Sensitive to lignin content } \\
\text { - } & \text { Complicated intermediates } \\
\text { during cultivation }\end{array}$ & [127] \\
\hline
\end{tabular}

The merits and drawbacks of different pretreatment for lignocellulosic biomass are shown in Table 4, which summarizes both merits and drawbacks of some widely deployed pretreatment approaches (physical, chemical, and biological) for lignocellulosic biomass fractionation. Although the pretreatment processes for lignocellulosic biomass utilizations have re-emerged into scope of research interests both in academia and industry during last two decades, alkaline delignification process with the aims of production of cellulose based paper pulp still is the undebatable mature and profitable process for commercial lignocellulosic biomass fractionation. The key technical hurdles for these commercial processes to overcome lie in the cost-effective retrofitting the existing downstream process that is able to integrated-utilizations of other compositions (decomposed hemicellulose and lignin) other than cellulose alone. In the meanwhile, breakthrough for alkaline recovery other than incineration of black liquor after delignification needed to be made so as to avoid bypassing the utilization of lignin and hemicellulose in black liquor by incineration (alkaline recovery during paper pulping) to realize the material recycling and energy cascade utilization. Apart from alkaline pretreatment, the dilute acid pretreatment had been found as one of the most mature and reliable process for lignocellulosic fractionation followed by subsequent utilization [128]. By considering maturity and reliability, the efforts paid upon these realms might potentially lead to a big engineering breakthrough.

The cost estimation of any developed process can be performed by studying the cost of the different components of the overall process. In the case of biomass pretreatment, these components include the cost of the biomass, equipment (fixing the CAPEX), chemicals, energy consumption, and operational expenses (depreciations, labors, plant overhead, etc.) during the process. The current status quo of economic analysis or cost estimation of biorefinery using lignocellulosic biomass mainly depends on the laboratory scale (some were conducted on pilot scale) experimental data and overall mass balances analysis to roughly estimate the associated CAPEX and OPEX costs [129]. Among the costs for different pretreatment process, the conventional acid hydrolysis are still among the most competitive and widely industrial adopted process for subsequent biorefinery such as ethanol and butanol productions [130]. For example, Kazi FK et al. performed the economic analysis of four different pretreatment processes namely, dilute acid, two-stage dilute acid, ammonia fiber expansion (AFEX), and hot water pretreatment. The result indicates that the highest ethanol yield of $289\left(\mathrm{~L} \cdot \mathrm{t}^{-1}\right)$ with lowest gasoline cost of 1.36 (US $\$ \cdot \mathrm{L}^{-1}$ ) of gasoline equivalent for dilute acid method [131]. According to André et al., total annual cost (TAC) of diluted acid hydrolysis process developed from national renewable energy laboratory (NREL) is still one of most competitive process achieving at $225 \mathrm{M} \$$, while liquid hot water (LHW) and AFEX processes are 328 and $359 \mathrm{M} \$$, respectively [132]. This might be the reasons that the numbers of available reported works focusing on using acid hydrolysis for pretreatment are still quite high. In this work, a potential process for the integrated utilization of biomass combining the 
conventional mature thermal process with DF to produce $\mathrm{BioH}_{2}$ is proposed and depicted in Figure 8 . The selection of biomass compounds for conversion into hydrogen depends heavily on the inherent physical and chemical features of three main compositions (hemicellulose, lignin, and cellulose). Taking lignin (mainly available from industrial black liquor) for example, containing large amount of aromatic compounds (resin like materials with relative higher heating value), it might be an appealing precursor for hydrogen generation via conventional thermal approaches such as gasification and steam reforming $[133,134]$.

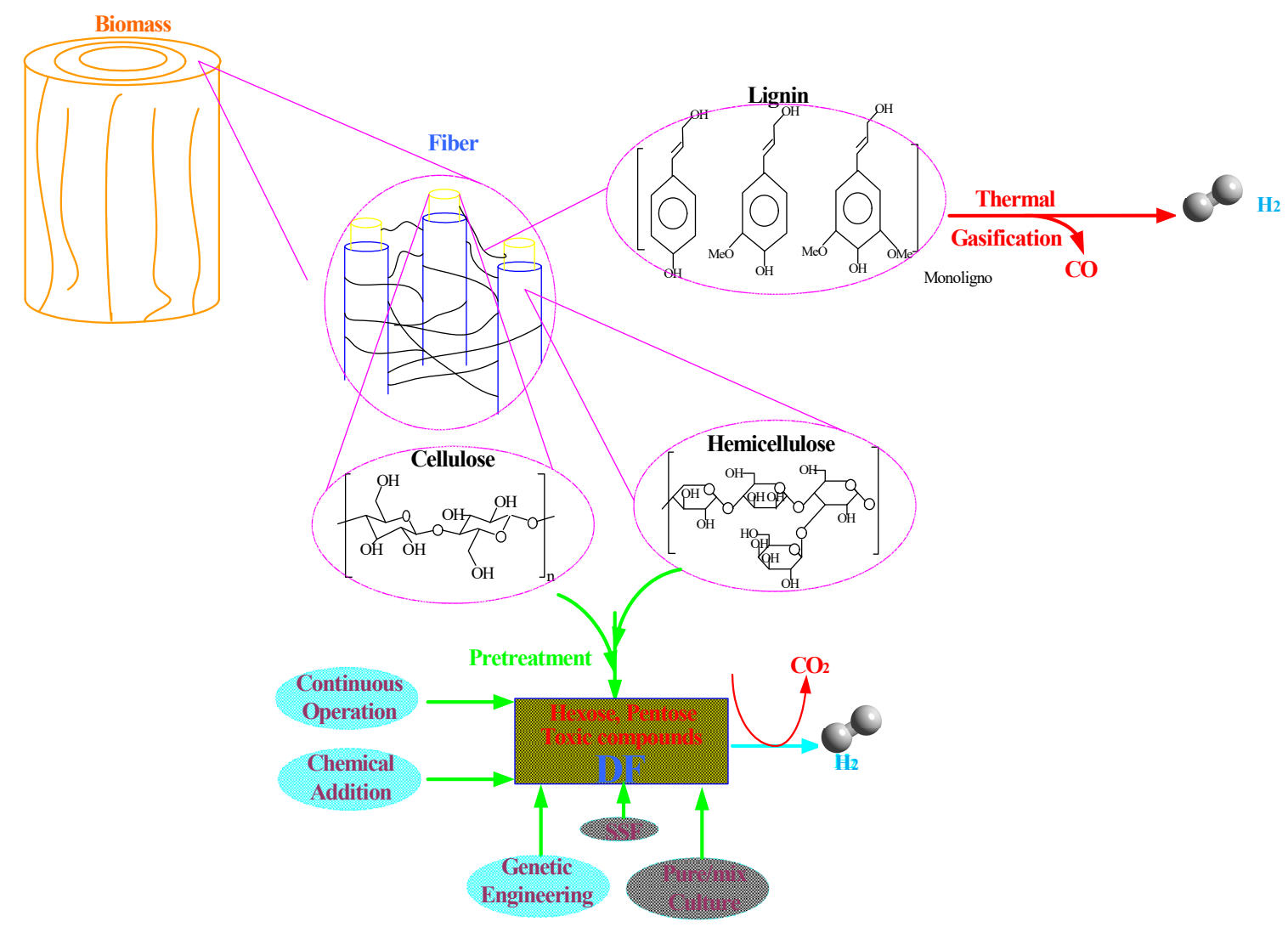

Figure 8. $\mathrm{BioH}_{2}$ production using lignocellulosic precursor (second generation feedstock) and process intensifications, where DF refers to dark fermentation and SSF refers to simultaneous saccharification and fermentation.

The hydrolysis of polysaccharide (cellulose and hemicellulose) also needs proper manipulation prior to the fermentation process. Therefore, the additional buffering or adjustable units that are able to adjust the optimal ratio of the reducible sugars and the main inhibitors are necessary prior to fermentation process. In addition, the careful selection of process intensification approach is needed as the matrix of fermentation broth from polysaccharide hydrolysate varies significantly. The necessity of using the mixed culture that is able to utilize different types of sugars (hexose and pentose) via different metabolic pathways needs to be carefully scrutinized in order to enhance $\mathrm{BioH}_{2}$ production. Furthermore, the effective incorporation of approaches such as long term continuous operation and chemical additions (biochar and nanoparticles) will be helpful in further boosting $\mathrm{BioH}_{2}$ production if the genetic stability and recovering the chemical additions could be cost-effectively improved. However, the challenges of this proposed integrated process still lies in: (a) the cost-effective fractionation of the three main compositions from biomass, (b) how to optimize the feed compositions in the fermentation broth, as assessed from ANNs study that the glucose/acetate/inhibitor needs to be maintained to a certain preferable range if natural microbial strains are inoculated, (c) the availability of large amount of water onsite, (d) the cost-effective $\mathrm{CO}_{2}$ separation and utilization, (e) the recycling of 
the hydrolysate and cost-effective $\mathrm{pH}$ swing process with nearly zero emission, and (f) a comprehensive life circle analysis (LCA) for the total process.

\section{Conclusions}

The collected reference reports using lignocellulosic biomass for $\mathrm{BioH}_{2}$ production were deployed for supervised machine learning via the constructed artificial neuron networks (ANNs) using feed backward propagation together with one cross-out validation approach to construct statistical and quantitative correlations between inputs of data matrix (including carbon sources i.e., glucose, xylose, and inhibitors i.e., acetate, furfural, and aromatic compounds) and outputs (including hydrogen yield (HY) and hydrogen evolution rate (HER)). The statistical analysis indicates that the optimal compositions of glucose (around $14 \mathrm{~g} \cdot \mathrm{L}^{-1}$ ) and acetate (around $1.3 \mathrm{~g} \cdot \mathrm{L}^{-1}$ ) will yield optimal HY $\left(3 \mathrm{H}_{2} \mathrm{~mol} \cdot \mathrm{mol}^{-1}\right.$ substrate and maximum HER, which are independent to the microbial strains and approaches of operations among the investigated literature reports. The comparative studies also indicate that the larger electron sinks in the acetate is found to be appreciably related to relatively higher HY and HER. Apart from the selection of microbial strains with exceptional higher capacity in hydrogen productions, which is still potentially substantial approach for the improvement of $\mathrm{BioH}_{2}$ production, other process intensifications using continuous operation compounded with synergistic chemical additions might also enhance the $\mathrm{BioH}_{2}$ productions during dark fermentation. The integrated utilization of lignocellulosic biomass for the hydrogen production relies on the seamless coupling of conventional mature thermal hydrogen generation process with the highly effective and process enhanced biological hydrogen production route.

Supplementary Materials: The following are available online at http://www.mdpi.com/1996-1073/13/10/2451/s1. Table S1. Four factor experimental design with ANNs simulated results of dependent variables, where Glu, Xyl, Acetate, Inh, HY, and HER refer to glucose, xylose, acetate, inhibitor, hydrogen yield, and hydrogen evolution rate, respectively. Table S2. ANOVA analysis for $\mathrm{HY}\left(\mathrm{r}^{2} 0.97\right.$, Adjust $\mathrm{r}^{2} 0.93$, Predicted $\mathrm{r}^{2}$ 0.94, adequate precision 16), and HER $\left(r^{2} 0.95\right.$, Adjust $r^{2}$ 0.94, Predicted $r^{2}$ 0.92, adequate precision 16), where $X 1$ is Glucose, $X 2$ is $X y l o s e, X 3$ is Acetate, and X4 is inhibitors. Table S3. The ANNs simulated quadratic coefficients for HY and HER. Table S4. $M S E$ and MARR of the cross validation based upon trained data sets.

Author Contributions: Y.L. drafted and compiled the whole manuscript, J.L. contributed to draw some schematic diagrams, J.M., X.F., Y.H., and Y.W. were responsible for some references collections. J.H. and H.D. helped to write and proofread the manuscript. G.Y. helped to revise and compiled rejoinder. V.S. and Y.S. supervised and managed whole project including (writing, revisions, and proofreading). All authors have read and agreed to the published version of the manuscript.

Funding: This research was funded by National Key R\&D Program of China (2018YFC1903500), National Natural Science of China (21850410456), University of Nottingham Faculty Inspiration Grant (FIG2019), Zhejiang provincial department of human resources (QJD1803014), Zhejiang Basic and Commonweal Research Programme (2017C510001 and 2019C10033).

Acknowledgments: Authors would like to sincerely appreciate the critical and insightful comments that raised from four anonymous reviewers in significantly improving the quality of this work.

Conflicts of Interest: The authors declare no competing financial interest.

\section{References}

1. Schlapbach, L.; Zuttel, A. Hydrogen-storage materials for mobile applications. Nature 2001, 414, $353-358$. [CrossRef] [PubMed]

2. Sun, Y.; He, J.; Yang, G.; Sun, G.; Sage, V. A Review of the Enhancement of Bio-Hydrogen Generation by Chemicals Addition. Catalysts 2019, 9, 353. [CrossRef]

3. Davis, S.J.; Lewis, N.S.; Shaner, M.; Aggarwal, S.; Arent, D.; Azevedo, I.L.; Benson, S.M.; Bradley, T.; Brouwer, J.; Chiang, Y.M.; et al. Net-zero emissions energy systems. Science 2018, 360, 1419. [CrossRef] [PubMed]

4. Oshiro, K.; Masui, T.; Kainuma, M. Transformation of Japan's energy system to attain net-zero emission by 2050. Carb. Manag. 2018, 9, 493-501. [CrossRef] 
5. Hepburn, C.; Adlen, E.; Beddington, J.; Carter, E.A.; Fuss, S.; Dowell, N.M.; Minx, J.C.; Smith, P.; Williams, C.K. The technological and economic prospects for CO2 utilization and removal. Nature 2019, 575, 87-97. [CrossRef]

6. Sun, Y.; Yang, G.; Zhang, L.; Sun, Z. Fischer-Tropsch synthesis in a microchannel reactor using mesoporous silica supported bimetallic Co-Ni catalyst: Process optimization and kinetic modeling. Chem. Eng. Process. 2017, 119, 44-61. [CrossRef]

7. Sun, Y.; Jia, Z.; Yang, G.; Zhang, L.; Sun, Z. Fischer-Tropsch synthesis using iron based catalyst in a microchannel reactor: Performance evaluation and kinetic modeling. Int. J. Hydrog. Energy 2017, 42, 29222-29235. [CrossRef]

8. Lu, X.F.; Yu, L.; Lou, X.W. Highly crystalline Ni-doped FeP/carbon hollow nanorods as all-pH efficient and durable hydrogen evolving electrocatalysts. Sci Adv. 2019, 5, eaav6009. [CrossRef]

9. Wei, W.; Sun, P.Q.; Li, Z.; Song, K.S.; Su, W.Y.; Wang, B.; Liu, Y.Z.; Zhao, J. A surface-display biohybrid approach to light-driven hydrogen production in air. Sci Adv. 2018, 4, eaap9253. [CrossRef]

10. Sun, Y.; Yang, G.; Wen, C.; Zhang, L.; Sun, Z. Artificial neural networks with response surface methodology for optimization of selective $\mathrm{CO} 2$ hydrogenation using K-promoted iron catalyst in a microchannel reactor. J. CO2 Util. 2018, 23, 10-21. [CrossRef]

11. Chava, R.K.; Do, J.; Kang, M. Strategy for improving the visible photocatalytic H-2 evolution activity of 2D graphitic carbon nitride nanosheets through the modification with metal and metal oxide nanocomponents. Appl. Catal. B-Environ. 2019, 248, 538-551. [CrossRef]

12. Wentorf, R.H.; Hanneman, R.E. Thermochemical Hydrogen Generation. Science 1974, 185, 311-319. [CrossRef] [PubMed]

13. Wismann, S.T.; Engbaek, J.S.; Vendelbo, S.B.; Bendixen, F.B.; Eriksen, W.L.; Aasberg-Petersen, K.; Frandsen, C.; Chorkendorff, I.; Mortensen, P.M. Electrified methane reforming: A compact approach to greener industrial hydrogen production. Science 2019, 364, 756. [CrossRef] [PubMed]

14. Sun, Y.; Zhang, J.P.; Yang, G.; Li, Z.H. An improved process for preparing activated carbon with large specific surface area from corncob. Chem. Biochem. Eng. Q. 2007, 21, 169-174.

15. Deluga, G.A.; Salge, J.R.; Schmidt, L.D.; Verykios, X.E. Renewable hydrogen from ethanol by autothermal reforming. Science 2004, 303, 993-997. [CrossRef]

16. Tuck, C.O. Valorization of biomass: Deriving more value from Waste. Science 2012, 337, 695-699. [CrossRef]

17. Shobana, S.; Kumar, G.; Bakonyi, P.; Saratale, G.D.; Al-Muhtaseb, A.H.; Nemestothy, N.; Belafi-Bako, K.; Xia, A.; Chang, J.S. A review on the biomass pretreatment and inhibitor removal methods as key-steps towards efficient macroalgae-based biohydrogen production. Bioresour. Technol. 2017, 244, 1341-1348. [CrossRef]

18. Nagarajan, D.; Lee, D.J.; Chang, J.S. Recent insights into consolidated bioprocessing for lignocellulosic biohydrogen production. Int. J. Hydrog. Energy 2019, 44, 14362-14379. [CrossRef]

19. Prabakar, D.; Manimudi, V.T.; Suvetha, K.S.; Sampath, S.; Mahapatra, D.M.; Rajendran, K.; Pugazhendhi, A. Advanced biohydrogen production using pretreated industrial waste: Outlook and prospects. Renew. Sustain. Energy Rev. 2018, 96, 306-324. [CrossRef]

20. Woodward, J.; Orr, M.; Cordray, K.; Greenbaum, E. Biotechnology-Enzymatic production of biohydrogen. Nature 2000, 405, 1014-1015. [CrossRef]

21. Bandyopadhyay, A.; Stöckel, J.; Min, H.; Sherman, L.A.; Pakrasi, H.B. High rates of photobiological $\mathrm{H} 2$ production by a cyanobacterium under aerobic conditions. Nat. Commun. 2010, 1, 1-7. [CrossRef] [PubMed]

22. Sivagurunathan, P.; Kumar, G.; Mudhoo, A.; Rene, E.R.; Saratale, G.D.; Kobayashi, T.; Xu, K.Q.; Kim, S.H.; Kim, D.H. Fermentative hydrogen production using lignocellulose biomass: An overview of pre-treatment methods, inhibitor effects and detoxification experiences. Renew. Sustain. Energy Rev. 2017, 77, $28-42$. [CrossRef]

23. Mishra, P.; Krishnan, S.; Rana, S.; Singh, L.; Sakinah, M.; Wahid, Z. Outlook of fermentative hydrogen production techniques: An overview of dark, photo and integrated dark-photo fermentative approach to biomass. Energy Strategy Rev. 2019, 24, 27-37. [CrossRef]

24. Trchounian, K.; Sawers, R.G.; Trchounian, A. Improving biohydrogen productivity by microbial dark- and photo-fermentations: Novel data and future approaches. Renew. Sustain. Energy Rev. 2017, 80, 1201-1216. [CrossRef] 
25. Khan, M.A.; Ngo, H.H.; Guo, W.S.; Liu, Y.W.; Zhang, X.B.; Guo, J.B.; Chang, S.W.; Nguyen, D.D.; Wang, J. Biohydrogen production from anaerobic digestion and its potential as renewable energy. Renew. Energy 2018, 129, 754-768. [CrossRef]

26. Trad, Z.; Fontaine, J.P.; Larroche, C.; Vial, C. Multiscale mixing analysis and modeling of biohydrogen production by dark fermentation. Renew. Energy 2016, 98, 264-282. [CrossRef]

27. Azwar, M.Y.; Hussain, M.A.; Abdul-Wahab, A.K. Development of biohydrogen production by photobiological, fermentation and electrochemical processes: A review. Renew. Sustain. Energy Rev. 2014, 31, 158-173. [CrossRef]

28. Nagarajan, D.; Lee, D.J.; Kondo, A.; Chang, J.S. Recent insights into biohydrogen production by microalgae-From biophotolysis to dark fermentation. Bioresour. Technol. 2017, 227, 373-387. [CrossRef]

29. Nissila, M.E.; Lay, C.H.; Puhakka, J.A. Dark fermentative hydrogen production from lignocellulosic hydrolyzates-A review. Biomass Bioenerg. 2014, 67, 145-159. [CrossRef]

30. Ren, N.Q.; Zhao, L.; Chen, C.; Guo, W.Q.; Cao, G.L. A review on bioconversion of lignocellulosic biomass to H-2: Key challenges and new insights. Bioresour. Technol. 2016, 215, 92-99. [CrossRef]

31. Wang, J.; Bibra, M.; Venkateswaran, K.; Salem, D.R.; Rathinam, N.K.; Gadhamshetty, V.; Sani, R.K. Biohydrogen production from space crew's waste simulants using thermophilic consolidated bioprocessing. Bioresour. Technol. 2018, 255, 349-353. [CrossRef] [PubMed]

32. Sun, Y.; Yang, G.; Xu, M.; Xu, J.; Sun, Z. A simple coupled ANNs-RSM approach in modeling product distribution of Fischer-Tropsch synthesis using a microchannel reactor with Ru-promoted $\mathrm{Co} / \mathrm{Al}_{2} \mathrm{O}_{3}$ catalyst. Int. J. Energy Res. 2020, 44, 1046-1061. [CrossRef]

33. Morra, S.; Arizzi, M.; Allegra, P.; la Licata, B.; Sagnelli, F.; Zitella, P.; Gilardi, G.; Valetti, F. Expression of different types of [FeFe]-hydrogenase genes in bacteria isolated from a population of a bio-hydrogen pilot-scale plant. Int. J. Hydrog. Energy 2014, 39, 9018-9027. [CrossRef]

34. Peters, J.W.; Schut, G.J.; Boyd, E.S.; Mulder, D.W.; Shepard, E.M.; Broderick, J.B.; King, P.W.; Adams, M.W.W. [FeFe]-and [NiFe]-hydrogenase diversity, mechanism, and maturation. BBA-Mol. Cell Res. 2015, 1853, 1350-1369. [CrossRef] [PubMed]

35. Lubitz, W.; Reijerse, E.; van Gastel, M. [NiFe] and [FeFe] hydrogenases studied by advanced magnetic resonance techniques. Chem. Rev. 2007, 107, 4331-4365. [CrossRef]

36. Pohorelic, B.K.J.; Voordouw, J.K.; Lojou, E.; Dolla, A.; Harder, J.; Voordouw, G. Effects of deletion of genes encoding Fe-only hydrogenase of Desulfovibrio vulgaris Hildenborough on hydrogen and lactate metabolism. J. Bacteriol. 2002, 184, 679-686. [CrossRef]

37. Vignais, P.M.; Billoud, B. Occurrence, classification, and biological function of hydrogenases: An overview. Chem. Rev. 2007, 107, 4206-4272. [CrossRef]

38. Kucharska, K.; Holowacz, I.; Konopacka-Lyskawa, D.; Rybarczyk, P.; Kaminski, M. Key issues in modeling and optimization of lignocellulosic biomass fermentative conversion to gaseous biofuels. Renew. Energy 2018, 129, 384-408. [CrossRef]

39. Sun, Y.; Wang, Y.; Yang, G.; Sun, Z. Optimization and enhancement of biohydrogen production using acid pretreated corn stover hydrolysate followed by nickel nanoparticle addition. Int. J. Energy Res. 2020, 44, 1843-1857. [CrossRef]

40. Benisch, F.; Boles, E. The bacterial Entner-Doudoroff pathway does not replace glycolysis in Saccharomyces cerevisiae due to the lack of activity of iron-sulfur cluster enzyme 6-phosphogluconate dehydratase. J. Biotechnol. 2014, 171, 45-55. [CrossRef]

41. Shuler, M.L.; Kargi, F.; DeLisa, M. Bioprocess Engineering: Basic Concepts, Prentice-Hall International Series in the Physical and Chemical Engineering Sciences; Prentice Hall: Upper Saddle River, NJ, USA, 2017.

42. Sun, Y.; Yang, G.; Zhang, J.P.; Wen, C.; Sun, Z. Optimization and kinetic modeling of an enhanced bio-hydrogen fermentation with the addition of synergistic biochar and nickel nanoparticle. Int. J. Energy Res. 2019, 43, 983-999. [CrossRef]

43. Anderson, K.A.; Madsen, A.S.; Olsen, C.A.; Hirschey, M.D. Metabolic control by sirtuins and other enzymes that sense NAD+, NADH, or their ratio. BBA-Bioenergetics 2017, 1858, 991-998. [CrossRef]

44. Sankaran, R.; Cruz, R.A.P.; Pakalapati, H.; Show, P.L.; ChuanLing, T.; Chen, W.-H. YangTao Recent advances in the pretreatment of microalgal and lignocellulosic biomass: A comprehensive review. Bioresour. Technol. 2020, 298, 122476-122486. [CrossRef] [PubMed] 
45. Jambo, S.A.; Abdulla, R.; Azhar, S.H.M.; Marbawi, H.; Gansau, J.A.; Ravindra, P. A review on third generation bioethanol feedstock. Renew. Sustain. Energy Rev. 2016, 65, 756-769. [CrossRef]

46. Ruiz, C.A.S.; Baca, S.Z.; van den Broek, L.A.M.; van den Berg, C.; Wijffels, R.H.; Eppink, M.H.M. Selective fractionation of free glucose and starch from microalgae using aqueous two-phase systems. Algal Res. 2020, 46, 101801-101810. [CrossRef]

47. Alavijeh, R.S.; Karimi, K.; Wijffels, R.H.; van den Berg, C.; Eppink, M. Combined bead milling and enzymatic hydrolysis for efficient fractionation of lipids, proteins, and carbohydrates of Chlorella vulgaris microalgae. Bioresour. Technol. 2020, 309, 123321-123330. [CrossRef]

48. Yin, Z.; Zhu, L.; Li, S.; Hu, T.; Li, B. A comprehensive review on cultivation and harvesting of microalgae for biodiesel production: Environmental pollution control and future directions. Bioresour. Technol. 2020, 301, 122804-122823. [CrossRef]

49. Mathimani, T.; Mallick, N. A comprehensive review on harvesting of microalgae for biodiesel—Key challenges and future directions. Renew. Sustain. Energy Rev. 2018, 91, 1103-1120. [CrossRef]

50. Jiménez-Llanos, M.R.-C.J.; Rendón-Castrillón, L.; Ocampo-López, C. Sustainable biohydrogen production by Chlorella sp. microalgae: A review. Int. J. Hydrog. Energy 2020, 45, 8310-8328. [CrossRef]

51. Cao, G.L.; Ren, N.Q.; Wang, A.J.; Lee, D.J.; Guo, W.Q.; Liu, B.F.; Feng, Y.J.; Zhao, Q.L. Acid hydrolysis of corn stover for biohydrogen production using Thermoanaerobacterium thermosaccharolyticum W16. Int. J. Hydrog. Energy 2009, 34, 7182-7188. [CrossRef]

52. Datar, R.; Huang, J.; Maness, P.C.; Mohagheghi, A.; Czemik, S.; Chornet, E. Hydrogen production from the fermentation of corn stover biomass pretreated with a steam-explosion process. Int. J. Hydrog. Energy 2007, 32, 932-939. [CrossRef]

53. Li, D.M.; Chen, H.Z. Biological hydrogen production from steam-exploded straw by simultaneous saccharification and fermentation. Int. J. Hydrog. Energy 2007, 32, 1742-1748. [CrossRef]

54. Fan, Y.T.; Zhang, Y.H.; Zhang, S.F.; Hou, H.W.; Ren, B.Z. Efficient conversion of wheat straw wastes into biohydrogen gas by cow dung compost. Bioresour. Technol. 2006, 97, 500-505. [CrossRef] [PubMed]

55. Kongjan, P.; Angelidaki, I. Extreme thermophilic biohydrogen production from wheat straw hydrolysate using mixed culture fermentation: Effect of reactor configuration. Bioresour. Technol. 2010, 101, 7789-7796. [CrossRef]

56. Lo, Y.C.; Lu, W.C.; Chen, C.Y.; Chang, J.-S. Dark fermentative hydrogen production from enzymatic hydrolysate of xylan and pretreated rice straw by Clostridium butyricum CGS5. Bioresour. Technol. 2010, 101, 5885-5891. [CrossRef]

57. Phanduang, O.; Lunprom, S.; Salakkam, A.; Reungsang, A. Anaerobic solid-state fermentation of biohydrogen from microalgal Chlorella sp biomass. Int. J. Hydrog. Energy 2017, 42, 9650-9659. [CrossRef]

58. Panagiotopoulos, I.A.; Bakker, R.R.; de Vrije, T.; Koukios, E.G.; Claassen, P.A.M. Pretreatment of sweet sorghum bagasse for hydrogen production by Caldicellulosiruptor saccharolyticus. Int. J. Hydrog. Energy 2010, 35, 7738-7747. [CrossRef]

59. Shi, X.X.; Song, H.C.; Wang, C.R.; Tang, R.S.; Huang, Z.X.; Gao, T.R.; Xie, J. Enhanced bio-hydrogen production from sweet sorghum stalk with alkalization pretreatment by mixed anaerobic cultures. Int. J. Energy Res. 2010, 34, 662-672. [CrossRef]

60. Pawar, S.S.; Nkemka, V.N.; Zeidan, A.A.; Murto, M.; van Niel, E.W.J. Biohydrogen production from wheat straw hydrolysate using Caldicellulosiruptor saccharolyticus followed by biogas production in a two-step uncoupled process. Int. J. Hydrog. Energy 2013, 38, 9121-9130. [CrossRef]

61. Talluri, S.; Raj, S.M.; Christopher, L.P. Consolidated bioprocessing of untreated switchgrass to hydrogen by the extreme thermophile Caldicellulosiruptor saccharolyticus DSM 8903. Bioresour. Technol. 2013, 139, 272-279. [CrossRef]

62. Hu, B.B.; Zhu, M.J. Direct hydrogen production from dilute-acid pretreated sugarcane bagasse hydrolysate using the newly isolated Thermoanaerobacterium thermosaccharolyticum MJ1. Microb. Cell Fact. 2017, 16, 77. [CrossRef] [PubMed]

63. Lee, H.S.; Salerno, M.B.; Rittmann, B.E. Thermodynamic evaluation on $\mathrm{H} 2$ production in glucose fermentation. Environ. Sci. Technol. 2008, 42, 2401-2407. [CrossRef] [PubMed]

64. Bina, B.; Amin, M.M.; Pourzamani, H.; Fatehizadeh, A.; Ghasemian, M.; Mahdavid, M.; Taheri, E. Biohydrogen production from alkaline wastewater: The stoichiometric reactions, modeling, and electron equivalent. MethodsX 2019, 6, 1496-1505. [CrossRef] [PubMed] 
65. Reddy, K.; Nasr, M.; Kumari, S.; Kumar, S.; Gupta, S.K.; Enitan, A.M.; Bux, F. Biohydrogen production from sugarcane bagasse hydrolysate: Effects of $\mathrm{pH}, \mathrm{S} / \mathrm{X}, \mathrm{Fe}^{2+}$, and magnetite nanoparticles. Environ. Sci. Pollut. $R$. 2017, 24, 8790-8804. [CrossRef] [PubMed]

66. Mthethwa, N.P.; Nasr, M.; Bux, F.; Kumari, S. Utilization of Pistia stratiotes aquatic weed, for fermentative biohydrogen: Electron-equivalent balance, stoichiometry, and cost estimation. Int. J. Hydrog. Energy 2018, 43, 8243-8255. [CrossRef]

67. Amin, M.M.; Taheri, E.; Bina, B.; van Ginkel, S.W.; Ghasemian, M.; Puad, N.I.M.; Fatehizadeh, A. Electron flow of biological $\mathrm{H} 2$ production by sludge under simple thermal treatment: Kinetic study. J. Environ. Manag. 2019, 250, 109461. [CrossRef]

68. Song, Y.H.; Lu, Y.; Yu, L. Stoichiometry and Thermodynamic Analysis on Biohydrogen Production from Xylose by Klebsiella oxytoca GS-4-08. Energy Fuel 2019, 33, 356-361. [CrossRef]

69. Aceves-Lara, C.A.; Latrille, E.; Buffiere, P.; Bernet, N.; Steyer, J.P. Experimental determination by principal component analysis of a reaction pathway of biohydrogen production by anaerobic fermentation. Chem. Eng. Process.-Process. Intensif. 2008, 47, 1968-1975. [CrossRef]

70. Blanco, V.M.C.; Oliveira, G.H.D.; Zaiat, M. Dark fermentative biohydrogen production from synthetic cheese whey in an anaerobic structured-bed reactor: Performance evaluation and kinetic modeling. Renew. Energy 2019, 139, 1310-1319. [CrossRef]

71. Whang, L.M.; Lin, C.A.; Liu, I.C.; Wu, C.W.; Cheng, H.H. Metabolic and energetic aspects of biohydrogen production of Clostridium tyrobutyricum: The effects of hydraulic retention time and peptone addition. Bioresour. Technol. 2011, 102, 8378-8383. [CrossRef]

72. Sarma, S.; Anand, A.; Dubey, V.K.; Moholkar, V.S. Metabolic flux network analysis of hydrogen production from crude glycerol by Clostridium pasteurianum. Bioresour. Technol. 2017, 242, 169-177. [CrossRef] [PubMed]

73. Ciranna, A.; Santala, V.; Karp, M. Enhancing biohydrogen production of the alkalithermophile Thermobrachium celere. Int. J. Hydrog. Energy 2012, 37, 5550-5558. [CrossRef]

74. Wu, C.W.; Whang, L.M.; Cheng, H.H.; Chan, K.C. Fermentative biohydrogen production from lactate and acetate. Bioresour. Technol. 2012, 113, 30-36. [CrossRef] [PubMed]

75. Garcia-Depraect, O.; Leon-Becerril, E. Fermentative biohydrogen production from tequila vinasse via the lactate-acetate pathway: Operational performance, kinetic analysis and microbial ecology. Fuel 2018, 234, 151-160. [CrossRef]

76. Shanmugam, S.; Hari, A.P.A.; Mathimani, T.; Felix, L.O.; Pugazhendhi, A. Comprehensive review on the application of inorganic and organic nanoparticles for enhancing biohydrogen production. Fuel 2020, 270, 117453-117464. [CrossRef]

77. Nagarajan, D.; Chang, J.-S.; Lee, D.-J. Pretreatment of microalgal biomass for efficient biohydrogen production - Recent insights and future perspectives. Bioresour. Technol. 2020, 302, 122871-122885. [CrossRef]

78. Chen, R.; Wang, Y.Z.; Liao, Q.; Zhu, X.; Xu, T.F. Hydrolysates of lignocellulosic materials for biohydrogen production. BMB Rep. 2013, 46, 244-251. [CrossRef]

79. Pawar, S.S.; van Niel, E.W.J. Evaluation of assimilatory sulphur metabolism in Caldicellulosiruptor saccharolyticus. Bioresour. Technol. 2014, 169, 677-685. [CrossRef]

80. Ghimire, A.; Frunzo, L.; Pirozzi, F.; Trably, E.; Escudie, R.; Lens, P.N.L.; Esposito, G. A review on dark fermentative biohydrogen production from organic biomass: Process parameters and use of by-products. Appl. Energy 2015, 144, 73-95. [CrossRef]

81. Liu, B.F.; Xie, G.J.; Wang, R.Q.; Xing, D.F.; Ding, J.; Zhou, X.; Ren, H.Y.; Ma, C.; Ren, N.Q. Simultaneous hydrogen and ethanol production from cascade utilization of mono-substrate in integrated dark and photo-fermentative reactor. Biotechnol. Biofuels 2015, 8, 8. [CrossRef]

82. Taher, E.; Amin, M.M.; Pourzamani, H.; Fatehizadeh, A.; Ghasemian, M.; Bina, B. Comparison of Acetate-butyrate and Acetate-ethanol Metabolic Pathway in Biohydrogen Production. J. Med. Signals Sens. 2020, 8, 101-107.

83. Garcia-Depraect, O.; Valdez-Vazquez, I.; Rene, E.R.; Gomez-Romero, J.; Lopez-Lopez, A.; Leon-Becerril, E. Lactate- and acetate-based biohydrogen production through dark co-fermentation of tequila vinasse and nixtamalization wastewater: Metabolic and microbial community dynamics. Bioresour. Technol. 2019, 282, 236-244. [CrossRef] [PubMed] 
84. Mthethwa, N.P.; Nasr, M.; Kiambi, S.L.; Bux, F.; Kumari, S. Biohydrogen fermentation from Pistia stratiotes aquatic weed, using mixed and pure bacterial cultures. Int. J. Hydrog. Energy 2019, 44, 17720-17731. [CrossRef]

85. Lee, D.J.; Show, K.Y.; Su, A. Dark fermentation on biohydrogen production: Pure culture. Bioresour. Technol. 2011, 102, 8393-8402. [CrossRef] [PubMed]

86. Elsharnouby, O.; Hafez, H.; Nakhla, G.; el Naggar, M.H. A critical literature review on biohydrogen production by pure cultures. Int. J. Hydrog. Energy 2013, 38, 4945-4966. [CrossRef]

87. Song, W.; Ding, L.; Liu, M.; Cheng, J.; Zhou, J.; Li, Y.-Y. Improving biohydrogen production through dark fermentation of steam-heated acid pretreated Alternanthera philoxeroide by mutant Enterobacter aerogenes ZJU1. Sci. Total Environ. 2020, 716, 134695-134704. [CrossRef]

88. Mahato, R.K.; Kumar, D.; Rajagopalan, G. Biohydrogen production from fruit waste by Clostridium strain BOH3. Renew. Energy 2020, 153, 1368-1377. [CrossRef]

89. Shao, W.; Wang, Q.; Rupani, P.F.; Krishnan, S.; Ahmad, F.; Rezania, S.; Rashid, M.A.; Sha, C.; Din, M.F. Biohydrogen production via thermophilic fermentation: A prospective application of Thermotoga species. Energy 2020, 197, 117199. [CrossRef]

90. Sydney, E.B.; Novak, A.C.; Rosa, D.; Medeiros, A.B.P.; Brar, S.K.; Larroche, C.; Soccol, C.R. Screening and bioprospecting of anaerobic consortia for biohydrogen and volatile fatty acid production in a vinasse based medium through dark fermentation. Process. Biochem. 2018, 67, 1-7. [CrossRef]

91. Soares, L.A.; Rabelo, C.A.B.S.; Sakamoto, I.K.; Silva, E.L.; Varesche, M.B.A. Screening and Bioprospecting of Anaerobic Consortia for Biofuel Production Enhancement from Sugarcane Bagasse. Appl. Biochem. Biotech. 2020, 190, 232-251. [CrossRef]

92. Pimenta, C.J.; Costa, L.M.A.S.; Chalfoun, S.M.; Pereira, M.C.; Bastos, S.C.; Tavares, L.S. Utilization of agroindustrial residues as substrates for production of pectinolytic enzymes by the biological agent "G088". In Microorganisms in Industry and Environment: From Scientific and Industrial Research to Consumer Products; World Scientific Publishing Co Pte Ltd.: Hackensack, NJ, USA, 2011; pp. 564-568.

93. Alvarez-Guzman, C.L.; Oceguera-Contreras, E.; Ornelas-Salas, J.T.; Balderas-Hernandez, V.E.; de Leon-Rodriguez, A. Biohydrogen production by the psychrophilic G088 strain using single carbohydrates as substrate. Int. J. Hydrog. Energy 2016, 41, 8092-8100. [CrossRef]

94. Alvarez-Guzman, C.L.; Balderas-Hernandez, V.E.; Gonzalez-Garcia, R.; Ornelas-Salas, J.T.; Vidal-Limon, A.M.; la Cueva, S.C.; de Leon-Rodriguez, A. Optimization of hydrogen production by the psychrophilic strain G088. Int. J. Hydrog. Energy 2017, 42, 3630-3640. [CrossRef]

95. Soares, J.F.; Confortin, T.C.; Todero, I.; Mayer, F.D.; Mazutti, M.A. Dark fermentative biohydrogen production from lignocellulosic biomass: Technological challenges and future prospects. Renew. Sustain. Energ. Rev. 2020, 117, 109484-109500. [CrossRef]

96. Engliman, N.S.; Abdul, P.M.; Wu, S.Y.; Jahim, J.M. Influence of iron II, oxide nanoparticle on biohydrogen production in thermophilic mixed fermentation. Int. J. Hydrog. Energy 2017, 42, 27482-27493. [CrossRef]

97. Gadhe, A.; Sonawane, S.S.; Varma, M.N. Influence of nickel and hematite nanoparticle powder on the production of biohydrogen from complex distillery wastewater in batch fermentation. Int. J. Hydrog. Energy 2015, 40, 10734-10743. [CrossRef]

98. Veeramalini, J.B.; Selvakumari, I.A.E.; Park, S.; Jayamuthunagai, J.; Bharathiraja, B. Continuous production of biohydrogen from brewery effluent using co-culture of mutated Rhodobacter M 19 and Enterobacter aerogenes. Bioresour. Technol. 2019, 286, 121402. [CrossRef]

99. Castillo-Hernandez, A.; Mar-Alvarez, I.I. Moreno-Andrade, Start-up and operation of continuous stirred-tank reactor for biohydrogen production from restaurant organic solid waste. Int. J. Hydrog. Energy 2015, 40, 17239-17245. [CrossRef]

100. Escamilla-Alvarado, C.; Ponce-Noyola, T.; Rios-Leal, E.; Poggi-Varaldo, H.M. A multivariable evaluation of biohydrogen production by solid substrate fermentation of organic municipal wastes in semi-continuous and batch operation. Int. J. Hydrog. Energy 2013, 38, 12527-12538. [CrossRef]

101. Krupp, M.; Widmann, R. Biohydrogen production by dark fermentation: Experiences of continuous operation in large lab scale. Int. J. Hydrog. Energy 2009, 34, 4509-4516. [CrossRef]

102. Shu, Z.; Chen, H.; Di, X.Y.; Li, Y.F. The Operation Characteristics of Biohydrogen Production in Continuous Stirred Tank Reactor with Molasses. Adv. Mater. Res. 2011, 153, 613-618. [CrossRef] 
103. Mahmod, S.S.; Jahim, J.M.; Abdul, P.M. Pretreatment conditions of palm oil mill effluent POME, for thermophilic biohydrogen production by mixed culture. Int. J. Hydrog. Energy 2017, 42, 27512-27522. [CrossRef]

104. Ramprakash, B.; Muthukumar, K. Influence of sulfuric acid concentration on biohydrogen production from rice mill wastewater using pure and coculture of Enterobacter aerogenes and Citrobacter freundii. Int. J. Hydrog. Energy 2018, 43, 9254-9258. [CrossRef]

105. Arisht, S.N.; Abdul, P.M.; Liu, C.M.; Lin, S.K.; Maaroff, R.M.; Wu, S.Y.; Jahim, J.M. Biotoxicity assessment and lignocellulosic structural changes of phosphoric acid pre-treated young coconut husk hydrolysate for biohydrogen production. Int. J. Hydrog. Energy 2019, 44, 5830-5843. [CrossRef]

106. Taifor, A.F.; Zakaria, M.R.; Yusoff, M.Z.M.; Toshinari, M.; Hassan, M.A.; Shirai, Y. Elucidating substrate utilization in biohydrogen production from palm oil mill effluent by Escherichia coli. Int. J. Hydrog. Energy 2017, 42, 5812-5819. [CrossRef]

107. Damayanti, A.; Sediawan, W.B. Biohydrogen Production by Reusing Immobilized Mixed Culture in Batch System. Int. J. Hydrog. Energy 2020, 9, 37-42. [CrossRef]

108. Taheri, E.; Amin, M.M.; Fatehizadeh, A.; Pourzamani, H.; Bina, B.; Spanjers, H. Biohydrogen production under hyper salinity stress by an anaerobic sequencing batch reactor with mixed culture. J. Environ. Health Sci. 2018, 16, 159-170. [CrossRef]

109. Cao, G.L.; Ren, N.Q.; Wang, A.J.; Guo, W.Q.; Zhao, L. Development of AFEX-based consolidated bioprocessing for biohydrogen production. In Abstracts of Papers of the American Chemical Society; American Chemical Society: Washington, DC, USA, 2012; p. 243.

110. Cao, G.L.; Xia, X.F.; Zhao, L.; Wang, Z.Y.; Li, X.; Yang, Q. Development of AFEX-based consolidated bioprocessing on wheat straw for biohydrogen production using anaerobic microflora. Int. J. Hydrog. Energy 2013, 38, 15653-15659. [CrossRef]

111. Haris, T.K.; Kubra, N.A.; Azbar, A.N. Biohydrogen, 2nd ed.; Elsevier: Amsterdam, The Netherlands, 2019.

112. Kumar, B.; Bhardwaj, N.; Agrawal, K.; Chaturvedi, V.; Verma, P. Current perspective on pretreatment technologies using lignocellulosic biomass: An emerging biorefinery concept. Fuel Process. Technol. 2020, 199, 106244. [CrossRef]

113. Asomaning, J.; Haupt, S.; Chae, M.; Bressler, D.C. Recent developments in microwave-assisted thermal conversion of biomass for fuels and chemicals. Renew. Sustain. Energy Rev. 2018, 92, 642-657. [CrossRef]

114. Koutauarapu, R.; Reddy, C.V.; Babu, B.; Reddy, K.R.; Cho, M.; Shim, J. Carbon cloth/transition metals-based hybrids with controllable architectures for electrocatalytic hydrogen evolution-A review. Int. J. Hydrog. Energy 2020, 45, 7716-7740. [CrossRef]

115. Hassan, S.S.; Williams, G.A.; Jaiswal, A.K. Emerging technologies for the pretreatment of lignocellulosic biomass. Bioresour. Technol. 2018, 262,310-318. [CrossRef] [PubMed]

116. Sun, Y.; Yang, G.; Jia, Z.H.; Wen, C.; Zhang, L. Acid Hydrolysis of Corn Stover Using Hydrochloric Acid: Kinetic Modeling and Statistical Optimization. Chem. Ind. Chem. Eng. Q. 2014, 20, 531-539. [CrossRef]

117. Huang, G.L.; Shi, J.X.; Langrish, T.A.G. Environmentally friendly bagasse pulping with NH4OH-KOH-AQ. J. Clean Prod. 2008, 16, 1287-1293. [CrossRef]

118. Sun, Y.; Yang, G.; Zhang, J.P.; Yao, M.S. Clean Production of Corn Stover Pulp Using Koh+Nh4oh Solution and Its Kinetics during Delignification. Chem. Ind. Chem. Eng. Q. 2012, 18, 137-145. [CrossRef]

119. Bhatia, S.K.; Jagtap, S.S.; Bedekar, A.A.; Bhatia, R.K.; Yang, Y.-H. Recent developments in pretreatment technologies on lignocellulosic biomass: Effect of key parameters, technological improvements, and challenges. Bioresour. Technol. 2020, 300, 122724-122737. [CrossRef]

120. Rajendran, K.; Drielak, E.; Varma, V.S.; Muthusamy, S.; Kumar, G. Updates on the pretreatment of lignocellulosic feedstocks for bioenergy production-A review. Biomass Convers. Biorefinery 2018, 8, 471-483. [CrossRef]

121. Nemestothy, N.; Bakonyi, P.; Rozsenberszki, T.; Kumar, G.; Kook, L.; Kelemen, G.; Kim, S.H.; Belafi-Bako, K. Assessment via the modified gompertz-model reveals new insights concerning the effects of ionic liquids on biohydrogen production. Int. J. Hydrog. Energy 2018, 43, 18918-18924. [CrossRef]

122. Shafiei, M.; Karimi, K.; Taherzadeh, M.J. Techno-economical study of ethanol and biogas from spruce wood by NMMO-pretreatment and rapid fermentation and digestion. Bioresour. Technol. 2011, 102, 7879-7886. [CrossRef] 
123. Zabed, H.M.; Akter, S.; Yun, J.; Zhang, G.; Awad, F.N.; Qi, X. Recent advances in biological pretreatment of microalgae and lignocellulosic biomass for biofuel production. Renew. Sustain. Energy Rev. 2019, 105, 105-128. [CrossRef]

124. Zhao, S.G.; Li, G.D.; Zheng, N.; Wang, J.Q.; Yu, Z.T. Steam explosion enhances digestibility and fermentation of corn stover by facilitating ruminal microbial colonization. Bioresour. Technol. 2018, 253, 244-251. [CrossRef]

125. Kumari, D.; Singh, R. Pretreatment of lignocellulosic wastes for biofuel production: A critical review. Renew. Sustain. Energy Rev. 2019, 90, 877-891. [CrossRef]

126. Sindhu, R.; Binod, P.; Pandey, A. Biological pretreatment of lignocellulosic biomass-an overview. Bioresour. Technol. 2016, 199, 76-82. [CrossRef] [PubMed]

127. Soltanian, S.; Aghbashlo, M.; Almasi, F.; Hosseinzadeh-Bandbafha, H.; Nizami, A.S.; Ok, Y.S.; Lam, S.S.; Tabatabaei, M. A critical review of the effects of pretreatment methods on the exergetic aspects of lignocellulosic biofuels. Energy Convers Manag. 2020, 212, 112792-112803. [CrossRef]

128. Solarte-Toro, J.C.; Romero-Garcia, J.M.; Martinez-Patino, J.C.; Ruiz-Ramos, E.; Castro-Galiano, E.; Cardona-Alzate, C.A. Acid pretreatment of lignocellulosic biomass for energy vectors production: A review focused on operational conditions and techno-economic assessment for bioethanol production. Renew. Sustain. Energy Rev. 2019, 107, 587-601. [CrossRef]

129. Jang, M.O.; Choi, G. Techno-economic analysis of butanol production from lignocellulosic biomass by concentrated acid pretreatment and hydrolysis plus continuous fermentation. Biochem. Eng. J. 2018, 134, 30-43. [CrossRef]

130. Romero, I.; Lopez-Linares, J.C.; Moya, M.; Castro, E. Optimization of sugar recovery from rapeseed straw pretreated with FeCl3. Bioresour. Technol. 2018, 268, 204-211. [CrossRef]

131. Kazi, F.K.; Fortman, J.A.; Anex, R.P.; Hsu, D.D.; Aden, A.; Dutta, A.; Kothandaraman, G. Techno-economic comparison of process technologies for biochemical ethanol production from corn stover. Fuel 2010, 89, S20-S28. [CrossRef]

132. Da Silva, A.R.G.; Ortega, C.E.T.; Rong, B. Techno-economic analysis of different pretreatment processes for lignocellulosic-based bioethanol production. Bioresour. Technol. 2016, 218, 561-570. [CrossRef]

133. Guan, G.Q.; Kaewpanha, M.; Hao, X.G.; Zhu, A.M.; Kasai, Y.; Kakuta, S.; Kusakabe, K.; Abudula, A. Steam reforming of tar derived from lignin over pompom-like potassium-promoted iron-based catalysts formed on calcined scallop shell. Bioresour. Technol. 2013, 139, 280-284. [CrossRef]

134. Han, T.; Yang, W.; Jönsson, P.G. Pyrolysis and subsequent steam gasification of metal dry impregnated lignin for the production of H2-rich syngas and magnetic activated carbon. Chem. Eng. J. 2020, 394, 124902-124912. [CrossRef]

(C) 2020 by the authors. Licensee MDPI, Basel, Switzerland. This article is an open access article distributed under the terms and conditions of the Creative Commons Attribution (CC BY) license (http://creativecommons.org/licenses/by/4.0/). 